\title{
GOLD INTO BASE METALS: \\ PRODUCTIVITY GROWTH IN THE PEOPLE'S \\ REPUBLIC OF CHINA DURING THE REFORM PERIOD
}

\author{
Alwyn Young \\ Working Paper 7856 \\ http://www.nber.org/papers/w7856 \\ NATIONAL BUREAU OF ECONOMIC RESEARCH \\ 1050 Massachusetts Avenue \\ Cambridge, MA 02138 \\ August 2000
}

I am grateful of Robert McCulloch for many useful conversations and to my colleagues at the CIAR for helpful feedback. This research was supported by the Canadian Institute for Advanced Research. The views expressed herein are those of the author and not necessarily those of the National Bureau of Economic Research.

(C) 2000 by Alwyn Young. All rights reserved. Short sections of text, not to exceed two paragraphs, may be quoted without explicit permission provided that full credit, including $(\mathcal{C}$ notice, is given to the source. 
Gold into Base Metals: Productivity Growth in the People's Republic of China during the Reform Period

Alwyn Young

NBER Working Paper No. 7856

August 2000

JEL No. O4, P2

\begin{abstract}
With minimal sleight of hand, it is possible to transform the recent growth experience of the People's Republic of China from the extraordinary into the mundane. Systematic understatement of inflation by enterprises accounts for $2.5 \%$ growth per annum in the non-agricultural economy during the reform period (1978-1998). The usual suspects, i.e. rising participation rates, improvements in educational attainment, and the transfer of labour out of agriculture, account for most of the remainder. The productivity performance of the non-agricultural economy during the reform period is respectable, but not outstanding. To the degree that the reforms have improved efficiency, these gains may lie principally in agriculture.
\end{abstract}

\author{
Alwyn Young \\ Graduate School of Business \\ University of Chicago \\ Chicago, IL 60637 \\ and NBER \\ a-young2@uchicago.edu
}




\section{Introduction}

Between 1978 and 1998 GDP per capita in the People's Republic of China, as reported in official statistics, grew $8.0 \%$ per annum, a performance which makes China the most rapidly growing economy in the world during this period, as well as all of recorded human history. ${ }^{1}$ While the unprecedented growth of the Chinese economy can be taken as evidence of the success of its economic reforms, its breathtaking magnitude and inordinate endurance has led others to seek less favourable, statistical, explanations. Thus, Summers and Heston, in version 5.6 of their popular international data set, cite the fact that "it is widely felt that [China's] growth rates are too high" and, accordingly, arbitrarily lower the reported growth of consumption and investment during the 1980-1993 period by 30 percent and 40 percent, respectively [Summers and Heston 1994]. In this paper I take a slightly different approach. Rather than discount the Chinese statistical record, I embrace it. Accepting all the numbers the statisticians of the People's Republic produce, but making systematic adjustments using their own data, I show that one can (a) reduce the growth rate during the reform period to levels previously experienced by other rapidly growing economies, so that (b) once one takes into account rising labour force participation, the transfer of labour out of agriculture and improvements in educational attainment, labour and total factor productivity growth in the non-agricultural economy are found to be 2.6 and 1.4 percent per annum, respectively; a respectable performance, but by no means extraordinary.

This paper proceeds as follows: In Sections II-VI I explain, step by step, how I derive estimates of output, labour input, human capital, physical capital, and factor income shares. In these sections I discuss problems with Chinese statistics and the basis on which I have chosen among alternative series. While the estimated growth of productivity is lowered by some choices (e.g. when I substitute alternative price indices, showing higher rates of inflation, for the national accounts deflators), it is raised by others (e.g. when I substitute a slower growing labour series

\footnotetext{
${ }^{1}$ All growth rates cited in this paper are $1 n$ growth rates, while all data, unless otherwise noted, come from the annual issues of the China Statistical Yearbook (hereafter, CSY).
} 
for the official data). In each case, however, I follow the precept of accepting the Chinese statistical record, making adjustments only when other official series are available, and then only in cases where the deficiencies of the commonly emphasized measures are well known or easily recognized. Section VII brings the different components together, estimating total factor productivity growth in the non-agricultural economy, while Section VIII concludes the paper.

The data of most economies are filled with apparently inconsistent series. By choosing amongst these, one can produce almost any estimate of productivity growth imaginable. Consequently, the only value added in a paper of this sort lies in its treatment and exposition of data, following which the actual total factor productivity results are a mere afterthought. In this paper I depart from standard practice, minimizing the discussion of productivity methodology and results, and devoting almost the entire paper to a discussion of Chinese data. To keep the task manageable, I focus on the reform period (1978-98) alone, eschewing any temptation to delve into the data of the plan period, which involve a variety of additional issues. I explore the construction and biases of each of the alternative data series available for the reform period. In the process, I show that the measures of outputs and inputs I select, combined with other data on the Chinese economy, form an internally consistent whole, with, for example, my measures of labour growth matching demographic and participation trends, as well as output, wage and factor share data. Readers can, however, see the steps I take to reach this conclusion and decide what problems exist in my methods and what alternatives they would prefer.

This paper restricts its analysis of total factor productivity growth to the non-agricultural sector. Land is of great importance in agriculture, but any measure of this input faces the formidable problem of its proper valuation relative to the other elements of the economy's capital stock. Land, however, plays less of a role in the non-agricultural segments of the economy. ${ }^{2}$ In developing economies much of the investment in agriculture involves livestock and labour inten-

\footnotetext{
${ }^{2}$ For example, Kim and Park [1985, table 5-13] estimate that land input accounts for only 4
} percent of Korean nonagricultural nonresidential income during the 1960s and 1970s. 
sive land improvement (e.g. irrigation works). These are rarely captured in the national accounts measures of capital investment in machinery and construction which fuel the capital stock estimates of most total factor productivity studies. Finally, the annual yield of agriculture is heavily influenced by the weather, which has to be controlled for in estimating productivity growth. In sum, the study of agriculture, while of great importance, involves a host of unique data and estimation problems. I avoid these by concentrating on the non-agricultural economy alone. 


\section{Output}

China's national income statistics are, in the main, based upon the reports of local officials, which are passed up through the bureaucracy and aggregated to produce the national figures circulated by the State Statistical Bureau (SSB). Since officials are rewarded for superior performance and punished for failing to meet targets, it is not surprising that they have a tendency to modify their statistical reports in accordance with central policy objectives, as has been documented, repeatedly, by none other than the Chinese themselves. ${ }^{3}$ Based upon press reports, official opinion appears to be that local officials overstate the growth of output, while understating investment and births. ${ }^{4}$ Absent a history of independent and comprehensive survey data there is no systematic way to evaluate or correct the bias in local reports. It is possible, however, to identify and quantify biases introduced by the statistical methods of the SSB. I discuss these, and possible corrections, in this section, examining problems in the measurement of nominal value added and the techniques used in its deflation.

${ }^{3}$ Some fairly frank reporting on the problem of statistical exaggeration, and its foundation in the incentives and rewards faced by lower level officials, can be found in the following sources (as reported and translated by the Foreign Broadcasting Information Service): Changsha Hunan Provincial Service 1100 GMT 1 December 1985; Cheng Ming No. 198, 1 April 1994, p. 1; Guangming Ribao 24 March 1995 p. 1; Hsin Pao 24 November 93 p. 22; Liaowang 20 February 1995 p. 1; Renmin Ribao 18 March 1985 p. 1, 13 February 1994 p. 2, 24 June 1994 p. 5, 17 August 1994 p. 1, and 15 December 1999 p. 4; Xinhua Domestic Service 0222 GMT 13 June 1994, 0513 GMT 17 January 1995, and 1013 GMT 2 March 1995; and Zhongguo Tongxun She 1137 GMT 1 January 1995.

I should note that the rewards for reporting good performance involve, in some cases, clearly stipulated targets and benefits. Thus, in some localities township officials "may be promoted to deputy county level positions so long as the output value of the township enterprises exceeds 100 million yuan" [Zhongguo Tongxun She 1137 GMT 1 Jan. 1995], while a State Council decree of 1984 established output targets, varying with population size, which would allow counties to be reclassified as cities, thereby automatically entitling them to a greater share of enterprise profits and, apparently, higher state subsidies [Chan 1994, pp. 273-276]. On the flip side, local officials may be punished for failing to meet particular targets, as reported, for example, in a Xinhua 1516 GMT 5 March 1995 broadcast.

${ }^{4}$ See Renmin Ribao 17 August 1994, p. 1 and 22 April 1995, p. 1, as well as Xinhua Domestic Service 2041 GMT 28 June 1995 broadcast. 


\section{a) Nominal Value Added}

With regards to the measurement of nominal quantities, the SSB's reluctance to revise downwards official figures and the approach it has taken in bringing its statistical system in line with international precepts have, arguably, imparted an upward bias to the growth of nominal value added in the industrial and service sectors.

The SSB appears reluctant to revise national accounts figures substantially downwards once these have been released. The most compelling example of this problem is given by the revision of the gross industrial output series which took place in the mid-1990s. In Table I below I report the original gross industrial output series, up to 1994. Following a nationwide audit of statistical reports, the 1994 gross industrial output estimates were revised downwards by about 9 percent, with most of the adjustment falling on township and village enterprises, whose output was deemed to have been exaggerated by about a third. As shown in the Table, the output series for earlier years was "smoothed" in accordance with the new, lower, output estimates. ${ }^{5}$ In the Table I also report the national accounts industrial value added series prior to and after the revision of the industrial output series. As the reader can see, national accounts industrial value added for 1994 was revised upwards, while for earlier years it was kept unchanged. Hsueh and Li, who in their 1999 publication provide a comprehensive official description of Chinese statistical methods, explain that the SSB estimates industrial value added by taking the gross output series and applying information on the use of intermediate inputs gleaned from its more detailed

\footnotetext{
${ }^{5}$ Following the 1995 Industrial Census, a new definition of gross output (excluding value added taxes and redefining the gross output measure for outsourced production) was introduced which reduced the gross output estimates further. The revised data for 1990-94, which drew upon reduced estimates of output, should not be confused with this later revision, based upon new definitions of output. The CSY 1997 clearly indicates that the revised 1990-1994 figures (presented above in Table I) are based on the old definitions and, in fact, links the old and new series by presenting comparable figures for 1995. Zhongguo Xinxi Bao 4 May 1995, p. 1 (as translated in the FBIS) also reports that the reduced estimates for 1994 and earlier were the result of the auditing and correction of exaggerated reports.
} 
surveys of "independent accounting" (principally, large and state) enterprises. ${ }^{6}$ Consequently, a 9 percent downward revision in the gross output series, with no change in the estimates for state enterprises, should have led to an equivalent downward revision of nominal value added. No such revision took place. While the Chinese government has conducted laudable campaigns against statistical misrepresentation, recording no less than 70,000 such cases in 1994 and 60,000 in $1997,,^{7}$ this information has difficulty in finding its way into revisions of the GDP estimates.

Regarding the service sector, under the "Material Planning System," i.e. the statistical system used under the plan, only the production and distribution of material goods was considered a source of output or income. Thus, freight transport, commerce, and even post were considered as output, but items such as passenger transport, real estate, television and radio broadcasting, education, research, finance, insurance, and public administration were not. With the exception of a few limited areas, such as passenger transport, where detailed statistics were kept through the years, the measurement of most service sectors was neglected. Consequently, when, during the reform period, the State Statistical Bureau switched to a "System of National Accounts," with its more standard definition of output and income, it was ill-equipped to provide a proper measure of the service sector. Acknowledgement of this defect led to the 1991-1992 Census of Services, which produced a dramatic revision of the national accounts.

Table II below reproduces the State Statistical Bureau's estimates of the GDP of the service (tertiary) sector, as reported in the China Statistical Yearbook. Beginning with the 1995 issue of the publication, the GDP estimates were revised on the basis of the data from the Census of Services. As the reader can see, the estimated value of service sector output in 1993 was

\footnotetext{
${ }^{6}$ This approach is consistent with that taken, in numerous areas, in other economies (see, also, Section VI below). Typically, aggregate information is limited to a few crude measures, such as gross output, which are then transformed into value added estimates using more detailed surveys of large enterprises.

${ }^{7}$ See Zhongguo Tongxun She 0730 GMT 23 February 1995, Zhongguo Xinxi Bao 4 May 1995 p. 1, and Beijing Xinhua 1014 GMT 25 January 1999.
} 
raised by about a third, while the estimates for 1978 were hardly changed at all. In other words, when the SSB improved its measure of the service sector, it concluded that virtually all the newly discovered, and hitherto unrecorded, value added had developed during the reform period. This assumption is retained, with minor revisions, in the most recent (1999) version of the national accounts. While the development of non-material sectors was neglected under the plan, so was their measurement. Consequently, the approach adopted by the SSB seems somewhat extreme, as it is likely that a fair amount of the newly discovered non-material output was present in 1978. As an alternative, one might assume that the ratio of unmeasured to measured activity found in 1993 existed in 1978 as well. If so, the SSB's adjustments overstate the growth of service sector nominal output between 1978 and 1993 by 1.6 percent per annum.

Despite the problems discussed above, in this paper I defer to the SSB estimates of nominal value added. Any assumption about the quantity of unmeasured service sector output in 1978 is equally arbitrary, while an adjustment of the entire industrial value added series based upon gross output revisions for the 1990-1994 period would be heroic in the extreme. The growth of industrial and service nominal value added may be overstated, but it cannot be credibly adjusted.

\section{b) Deflators}

The statisticians of most countries estimate real GDP by deflating nominal GDP using separate, independently constructed, price indices. This is not the procedure in the People's Republic. Beginning with the case of secondary industry (mining, manufacturing, utilities and construction), in China enterprises are called upon to report the value of output in current and constant (base year) prices. The difference between the two series produces an implicit deflator, which is then used to deflate nominal value added (also reported by the enterprises). Historically, this statistical method dovetailed neatly with the reporting requirements of the plan and, despite a general movement away from socialist statistical methods, remains in use today. In regard to the primary sectory (farming, fishing, forestry and animal husbandry), a similar 
approach is taken, although double deflation of value added is achieved by combining the enterprise implicit output deflators ${ }^{8}$ with separate price indices for intermediate inputs. Finally, in regards to the tertiary sector (services), a variety of methods are used, ranging from single deflation using enterprise provided implicit output deflators (telecommunications and wholesale and retail trade), to extrapolation using real volume indices (transport), to single deflation using specialized price indices, some of which are woefully inappropriate (e.g. interest rates in finance!) ${ }^{9}$ Despite these riders and exceptions, it is fair to say that, overall, the State Statistical Bureau remains heavily dependent upon enterprise-provided output-based implicit deflators to deflate nominal value added. ${ }^{10}$

Ruoen [1995] and Woo [1995] argue that the implicit deflators provided by Chinese enterprises are systematically biased. Enterprises are well aware of the current value of output and the nominal material value expended in its production, and so can easily report these to statistical officials. However, the construction of accurate constant price estimates in the base year of the SSB's choosing is an arduous task which, with the relaxation of government control over state

${ }^{8}$ As there has been a general privatization of agriculture during the reform period, the SSB uses reports from the remaining state and military farms, supplemented with surveys of the agricultural sector [Hsueh and Li 1999, p. 94].

${ }^{9}$ The use of nominal interest rates to deflate the loan income of banks would measure increases in the nominal value of loans brought about by inflation as an increase in the real volume of financial intermediation!

While the preceeding lays out the formal SSB statement of its procedures [Hsueh and $\mathrm{Li}$ 1999], there are indications that, in practice, these methods are not exactly followed. For example, the value added of wholesale, retail and restaurant trade is supposedly deflated using the enterprise implicit output deflators [lbid., p. 107]. However, between 1978 and 1982 the implicit deflator for this sector, in the national accounts, falls 16.6 percent per annum! During the same period, the overall GDP deflator rose 2.3 percent per annum and the retail price index rose 3.0 percent per annum. It is impossible to believe that even the most brazen enterprise directors would report a total collapse of final commercial prices during a period of moderate retail and GDP inflation.

${ }^{10}$ The expenditure side of the accounts depend more on independent price indices, but make use of a number of grossly incorrect procedures (e.g. using the consumption basket of government workers to deflate nominal government expenditure) to balance the two accounts. Section $V$ discusses the expenditure accounts in detail. 
enterprises and the development of non-state firms during the reform period, is increasingly unlikely to be seriously undertaken. Ruoen and Woo argue that many firms assume that the constant price value of output equals the nominal value, i.e. that the implicit deflator always equals one. This simplifying assumption has been taken by statisticians in other countries, ${ }^{11}$ and it seems likely that Chinese firms would find it to be a time saving approach. More generally, enterprises might assume that the inflation rate has some constant value. Regardless, the assumption of a constant inflation rate, be it zero or positive, will make the GDP deflators insufficiently responsive to a surge in the underlying rate of inflation, such as has occurred during the reform period. Fortunately, the State Statistical Bureau does, actually, compile independent price indices of its own. It simply doesn't use these to deflate output! Ruoen [1995] argues that these independent price indices can credibly substitute for the existing implicit deflators in the estimation of the growth of real output.

Table III below compares the average rates of inflation recorded by the implicit GDP deflators with those of the independent price indices compiled by the SSB. Beginning with the secondary sector, the Ex-Factory Industrial Price Index, recommended by Rouen as an alternative to the GDP deflator, covers the factory gate prices of raw materials, electric power, industrial and construction inputs, and commercial final goods. This index shows 1.7 percent more inflation per annum than the implicit secondary deflator. Alternatives to the Ex-Factory Price Index are the Industrial Products Rural Retail Price Index and the Retail Price Index. Both indices include the profit margins of commercial establishments. In addition, the coverage of the Industrial Products Rural Retail Price Index is, obviously, restricted to rural areas, while the Retail Price Index is basically a consumer goods index. Regressing the growth of the implicit secondary deflator on the growth of all three indices, I find that only the Ex-Factory index is sig-

\footnotetext{
${ }^{11}$ E.g. Singapore [Young 1995, p. 658].
} 
nificant. ${ }^{12}$ For all these reasons, the Ex-Factory price index is arguably a superior choice as a replacement deflator. It is significant, nevertheless, that during the reform period all three SSB price indices show more inflation than the implicit secondary deflator. The exaggeration of industrial output growth brought about by the use of enterprise deflators has also been independently confirmed by the SSB which, in a study of Hunan province for the period 1982-1987, found that a real quantity index, using individual commodity outputs, implied 3.9 percent less growth per annum than indicated by the implicit deflators [Rouen 1995, p. 86].

Turning to the primary sector, the long standing Farm and Sideline Products Purchasing Price Index, recommended by Ruoen as an alternative to the primary deflator, measures the average cost of primary sector goods purchased by commercial enterprises (of all ownership types), covering products as varied as grains, fruits, vegetables, meat, animal by-products (e.g. furs), fish and lumber. This index evinces somewhat less inflation than the implicit GDP deflator, lending no support to Ruoen and Woo's argument. ${ }^{13}$ Finally, for the tertiary sector, Ruoen suggests the use of the only available service price index, i.e. the Service Price Index subcomponent of the Consumer Price Index, which covers post and telecommunications, transport, housing, medical and child care, and other personal and recreational services. The service CPI grew out of the Staff and Worker Cost of Living Index, which, up until 1985, covered urban areas alone. Absent any alternative, I use the urban service price index for 1978 to 1985 , and the overall service price index thereafter. As shown in the Table, the service sector CPI reports the existence of substan-

\footnotetext{
${ }^{12}$ For the period 1978-1998, the coefficients in the regression of the growth of the implicit secondary deflator on the growth of the industrial products rural price index, the retail price index and the ex-factory price index are $-.16(.27), .17(.25)$, and $.64(.17)$, respectively (standard errors in parentheses). The industrial products rural price index and the retail price index are, individually, positively and significantly correlated with the secondary deflator, but only insofar as they are correlated with the ex-factory price index.

${ }^{13}$ This may partly be due to the fact that the implicit deflator is a double deflated value added price index. With the prices of agricultural goods rising relative to industrial intermediate inputs, the value added deflator will rise faster than the output deflator. Consequently, it is still possible that the agricultural enterprise output deflator grows less than the farm products price index.
} 
tially more inflation than is indicated by the implicit tertiary deflator.

Ruoen and Woo's hypothesis can be explored, more rigorously, using the stochastic properties of the different price indices. Formally, describe both the GDP deflators and the alternative price indices as imperfect measures of underlying inflation rates:

$$
\text { (1) } D_{i t}=\alpha_{i}+B_{i} \pi_{i t}+\varepsilon_{i t} \quad P_{i t}=\tau_{i}+\gamma_{i} \pi_{i t}+\eta_{i t}
$$

where i denotes the sector (primary, secondary and tertiary), $t$ is time, $D$ the growth of the implicit GDP deflator, $\mathrm{P}$ the growth of the alternative price index, $\alpha$ and $\tau$ are constants, $B$ and $\gamma$ measure the responsiveness of the different indices to movements in the underlying inflation rate, and $\varepsilon$ and $\eta$ are iid errors. Ruoen's suggestion that the alternative price indices be substituted for the implicit deflators is based upon the assumption that $\tau$ equals zero and $\gamma$ one, i.e. that the price indices are unbiased measures of underlying inflation. Maintaining this assumption, one can then estimate the following bi-factor latent variable model:

$$
\text { (2) Bi-factor model: } \quad D_{i t}=\alpha_{i}+B_{i} \pi_{i t}+\varepsilon_{i t} \quad P_{i t}=\pi_{i t}+\eta_{i t}
$$

If Rouen and Woo's argument concerning enterprise behavior is correct, then the estimate of $B$ should be significantly less than one. $B$ measures the fraction of output which is properly deflated, while $1-B$ is the faction of output produced by firms which assume that the inflation rate is some constant rate (perhaps zero).

Table IV below reports the results of the maximum likelihood full information estimation of the bi-factor model. Letting the vector $\mathbf{X}=\left(\mathrm{D}_{\mathrm{Pt}}, \mathrm{D}_{\mathrm{St}}, \mathrm{D}_{\mathrm{Tt}}, \mathrm{P}_{\mathrm{Pt}}, \mathrm{P}_{\mathrm{St}}, \mathrm{P}_{\mathrm{Tt}}\right)^{\prime}, \mathrm{I}$ constrain the covariance matrix of $\mathbf{X}\left(\Sigma_{\mathrm{X}}\right)$ to be the following function:

(3) $\Sigma_{\mathbf{x}}=\mathbf{B} \Sigma_{\pi} \mathbf{B}^{\prime}+\Sigma_{\varepsilon, \eta}$

where $\mathbf{B}$ is $6 \times 3$ matrix composed of a $3 \times 3$ diagonal matrix of the $B$ 's followed, below, by the $3 \times 3$ identity matrix, $\Sigma_{\pi}$ is the $3 \times 3$ covariance matrix of the underlying inflation rates, and $\Sigma_{\varepsilon, \eta}$ is a $6 \times 6$ diagonal matrix of the variance of the individual error terms. Identification of the $B$ 's comes from the covariance of the underlying sectoral inflation rates and the assumption, in the model, 
that the ratio of the covariance of each $\left(\mathrm{D}_{\mathrm{j}}, \mathrm{P}_{\mathrm{i}}\right)$ pair with the remaining $\mathrm{D}_{\mathrm{j}}$ 's and $\mathrm{P}_{\mathrm{j}}$ 's $(i \neq j)$ is given by $B_{i}{ }^{14}$ The analysis implicitly assumes that the price level is difference stationary, with intratemporally correlated, but intertemporally iid, inflation shocks. While the price level itself is unlikely to be trend reverting, it is likely that the inflation rate is intertemporally correlated and I hope, in a latter draft, to modify the analysis appropriately, using both the intratemporal and intertemporal covariance in the sectoral inflation rates to identify the $B$ 's, as well as including serial correlation in the errors and allowing for the possibility that the deflator bias has worsened through time. ${ }^{15}$ In Table IV I focus on the parameters directly relevant to the current discussion, reporting the remaining parameters in the appendix. ${ }^{16}$

${ }^{14}$ I should note that the more standard limited information IV and 2SLS methods are not quite appropriate for this model. Thus, for example, one could regress $D_{i}$ on the remaining $D_{j}$ and $\mathrm{P}_{\mathrm{j}}$ 's $(i \neq j)$, purging it of error, and then regress $\mathrm{P}_{\mathrm{j}}$ on the estimated value of $\mathrm{D}_{\mathrm{i}}$ to derive an estimate of $B_{i}$. However, one could just as easily regress $\mathrm{P}_{\mathrm{i}}$ on the remaining $\mathrm{D}_{\mathrm{j}}$ and $\mathrm{P}_{\mathrm{j}}$ 's $(i \neq j)$, purging $i t$ of error, and then regress $\mathrm{D}_{\mathrm{i}}$ on the estimated value, deriving an estimate of $1 / B_{i}$. As there is no causal relationship between $\mathrm{D}_{\mathrm{i}}$ and $\mathrm{P}_{\mathrm{i}}$, the model does not select one procedure over the other, and both are appropriate. However, they give different answers. The full information method I adopt above symmetrically combines the information contained in the relative covariance of $\mathrm{D}_{\mathrm{i}}$ and $\mathrm{P}_{\mathrm{i}}$ with the remaining price measures to estimate $B_{i}$. I should also note that IV and 2SLS methods would be difficult to apply to the extensions of the model I explore below, which, however, can be neatly folded into the full information framework.

${ }^{15}$ Assuming, that is, that the overall approach meets with approval.

${ }^{16}$ The only issue which arises is that, in a few cases, some of the individual variances in $\Sigma_{\varepsilon, \eta}$ are estimated to be zero, i.e. hit a corner (the appendix explains how I constrain the estimates to produce positive definite covariance matrices). This so-called Heywood case appears frequently in latent variable models with small samples and few variables per factor [see Loehlin 1998, p. 61]. In the context of the present model, it arises as follows: With the individual variances assumed to be positive, $B_{i}$ is estimated from the ratio of the covariance of $\mathrm{D}_{\mathrm{i}}$ with the remaining $\mathrm{D}_{\mathrm{j}}$ 's and $\mathrm{P}_{\mathrm{j}}$ 's to the covariance of $\mathrm{P}_{\mathrm{i}}$ with these variables. With $B_{i}$ determined in this fashion, the variance of inflation in sector $i$ is then estimated using the fact that the covariance between $\mathrm{D}_{\mathrm{i}}$ and $\mathrm{P}_{\mathrm{i}}$ is equal to $B_{i}{ }^{*} \operatorname{Var}\left(\pi_{i}\right)$. However, the variance of $\mathrm{P}_{\mathrm{j}}$ is given by $\operatorname{Var}\left(\pi_{\mathrm{j}}\right)+$ $\operatorname{Var}\left(\eta_{\mathrm{i}}\right)$. If, for example, the covariance between $D_{i}$ and $P_{i}$ is large, $\operatorname{Var}\left(\pi_{i}\right)$ is found to be large and $\operatorname{Var}\left(\eta_{i 1}\right)$ is driven to zero. In this case, $B_{i}$ is no longer solely determined by the relative covariance of $D_{i}$ and $P_{i}$ with the remaining variables, but is constrained by the covariance between $D_{i}$ and $P_{i}$ and the variance of $P_{i}$. I should note, however, that if one relaxes the nonnegativity constraints on the problem, and allows negative residual variances, the likelihood reaches a maximum with the offending residual variances very close to zero and a virtually unchanged ln likelihood, i.e. the non-negativity constraints are only mildly binding. Further, with the non-negativity constraints in place, the restriction on the covariance matrix described by (3) is not rejected. 
As shown in column (1) of Table IV, the stochastic properties of the different price measures strongly support Ruoen and Woo's hypothesis. The individual $B$ 's are all estimated to be less than 1 and, with standard errors taken from the inverse negative Hessian, significantly so in the case of the primary and secondary sectors. Since the standard results concerning maximum likelihood estimators are asymptotic, and the sample of 20 years used here is laughably small, I have taken the liberty of using the estimated parameters to randomly generate 500 similarly sized samples and reestimate the model on each of these. The mean value and standard errors of the parameters estimated from these simulations are also reported in Table IV. As indicated, for a problem of this sort the small sample MLE estimator appears to be fairly unbiased, and the standard errors drawn from the square root of the diagonal elements of the negative Hessian are off by no more than 10 to 20 percent. I also report, in the Table, the unrestricted ln likelihood for the sample covariance matrix. The restrictions imposed by equation (3) are not rejected, whether one uses the asymptotic or simulated test statistic. ${ }^{17}$

The lower rows of Table IV report the estimated average underlying rates of sectoral inflation. Since the bi-factor model laid out in equation (2) above assumes that the price indices are unbiased measures of the underlying inflation, these estimates are, trivially, the mean rates of inflation of the price indices. ${ }^{18}$ While the $B$ estimates of the bi-factor model are supportive of Ruoen and Woo's hypothesis, it would be nice to derive estimates of the underlying inflation rates that are not given by assumption. To this end, I have tried two approaches. In col umns (3)-(4) of Table IV I reestimate the bi-factor model, but constrain the estimate of the mean infla-

${ }^{17}$ Since for the simulated data the model is "true", I simply report the 95 th percentile for the difference between the restricted and unrestricted ln likelihoods.

${ }^{18}$ The mean values of these, in the simulated model, are slightly greater. This does not reflect bias in the estimation procedure, but rather a positive average realization of the stochastic shocks generated by Stata's pseudo random number generator (as the estimated mean inflation rates are simply the means of the realized random variables). 
tion rate by assuming that the $\alpha_{i}$ 's equal zero, ${ }^{19}$ so that the differences in the mean growth of the implicit deflators and alternative price indices have to be spanned by $B$ and the average underlying inflation rate:

(4) Constrained means: $\quad \bar{D}_{i}=B_{i} \bar{\pi}_{i} \quad \bar{P}_{i}=\bar{\pi}_{i}$

If the $B$ 's were equal to one, this approach would find the mean inflation rate as the weighted average of the growth of the deflator and the alternative price index, with the weights given by the variance of the opposing unique error variances:

(5) $\bar{\pi}_{i}=\bar{D}_{i} \frac{\sigma_{\eta}^{2}}{\sigma_{\varepsilon}^{2}+\sigma_{\eta}^{2}}+\bar{P}_{i} \frac{\sigma_{\varepsilon}^{2}}{\sigma_{\varepsilon}^{2}+\sigma_{\eta}^{2}}$

However, to the degree that $B_{i}$ can, without undo violence to the covariance matrix, equal $\bar{D}_{i} / \bar{P}_{i}$, the estimated mean underlying inflation rate simply equals the average growth of the alternative price index. As the reader can see from columns (3)-(4), the latter is basically the case. The estimated average inflation rates, in particular for the non-agricultural secondary and tertiary sectors, which form the focus of the analysis of this paper, are virtually unaffected by the mean constraint.

As an alternative approach, I begin by noting that the bi-factor model used in columns (1)-(4) is unable to separately identify the values of $B_{i}$ and $\gamma_{i}$ in equation (1) earlier. That is, while Table IV reports estimated values for $B$, these can really be thought of as the value of $B_{i} / \gamma_{i}$, with the assumption that $\gamma_{i}=1$ being a normalization that bundles the bias of the alternative price indices into the estimated variance of the underlying inflation rates. Thus, while the estimates are below one, the model does not rule out the possibility that the deflators are unbiased $\left(B_{i}=1\right)$, while the alternative price indices actually overstate the inflation rate $\left(\gamma_{i}>1\right)$. This could arise,

\footnotetext{
${ }^{19}$ In effect assuming that the misreporting enterprises posit a constant deflator, i.e. an inflation rate of zero.
} 
in particular, if the price indices were weighted toward products whose relative prices were systematically rising more rapidly. ${ }^{20}$

To get around this problem, I propose an alternative model of the form:

(6) Nominal shock model: $\quad P_{i t}=\alpha_{i}+B_{i}\left(\pi_{t}+v_{i t}\right)+\varepsilon_{i t} \quad D_{i t}=\pi_{t}+\gamma_{i} v_{i t}+\eta_{i t}$ where $\pi_{i t}=\pi_{t}+v_{i t}$

This model decomposes the sectoral price change into a nominal shock, common to all sectors, and sector specific real shocks. I assume that, from the point of view of enterprises, it does not matter what is the source of the sectoral price change, the bias will be the same. However, no price index, no matter what its weights, can overstate inflation when the price increase is common to all sectors and goods. Thus, if the price indices are biased $(\gamma \neq 1)$, this bias can only appear in their measurement of the price effects of real shocks. To the degree that the variance of the nominal shock is substantial, this model allows for the separate identification of B and $\gamma$. In the estimation, I allow the $v_{\text {it }}$ 's to covary with each other, but assume that the nominal shock is orthogonal to the remaining elements of the model. This "classical" assumption is pretty much forced, as the $6 \times 6$ covariance matrix has only 21 moments, and the model, as is, has 19 covariance-related parameters, ${ }^{21}$ which does not leave enough moments to allow for a general covariance between the nominal and real shocks.

Column (5) of Table IV reports the maximum likelihood estimate of the nominal shock model. All of the $B_{i}$ and $\gamma_{i}$ parameters are measured with great imprecision, as everything is leveraged off of the variation of the nominal shock. Nevertheless, based upon the point estimates, one could, indeed, argue that both the primary and secondary price indices overstate the

${ }^{20}$ As an example, consider a rise in the relative price of services brought about by its comparatively slower productivity growth. If the alternative price index is weighted toward service industries with the most laggard productivity growth, it will overstate overall service sector inflation.

${ }^{21}$ The six elements of the $v_{i t}$ covariance matrix, the variance of the nominal shock and the six specific shocks, and the three $B_{i}$ 's and three $\gamma_{i}$ 's. 
inflation caused by real shocks. Practically speaking, however, this turns out to be of little import. With the "free means" of column (5) one cannot identify the mean inflation rates, ${ }^{22}$ but if one constrains the deflator specific $\alpha_{i}$ 's to be zero, they can be estimated. Doing so, one finds $\bar{\pi}$ to be .056 , and $\bar{v}_{i}$ to be $.008, .004$, and .060 in the primary, secondary and tertiary sectors, respectively, i.e. with the exception of the tertiary sector, the nominal shock is the dominant force determining the average growth of prices. Consequently, despite the large $\gamma_{i}$ 's, the estimated rates of sectoral inflation (as reported in column (7)), are quite close to the growth of the alternative price indices. For the secondary and tertiary sectors, in particular, the mean rate of underlying inflation is about equal to, or exceeds, the growth of the corresponding alternative price indices (compare with column (1)).

To summarize, the joint stochastic behavior of the implicit GDP deflators and alternative price indices lends substantial support to Ruoen and Woo's argument that the implicit GDP deflators systematically understate price movements. Various attempts to allow the data to select its own inflation rate return estimates close to, if not exceeding, the growth of the alternative price indices. On this basis, I follow the suggestion of Ruoen, substituting the SSB price indices he recommends for the implicit deflators of the national accounts. Table V compares the official Chinese growth rates with the alternative estimates of GDP growth. ${ }^{23}$ As the Table shows, the use of the alternative SSB price indices to deflate output lowers the growth of aggregate and non-

${ }^{22}$ The sectoral deflators and price indices produce six means, but there are seven relevant parameters $\left(3 \bar{\alpha}_{i}^{\prime}\right.$ s, $3 \bar{v}_{i}$ 's, and $\left.\bar{\pi}\right)$.

${ }^{23}$ Official Chinese growth rates are computed using Laspeyres price weights. I compute aggregate growth rates as the Tornqvist weighted sum of the sectoral growth rates, i.e.:

$$
g(t)=\sum_{i} g_{i}(t)\left[\frac{s_{i}(t)+s_{i}(t-1)}{2}\right]
$$

where $s_{i}(t)$ is the share of sector $i$ in the nominal value added of year $t$, and $g_{i}(t)$ is the constant price growth of the output of sector i between years $\mathrm{t}-1$ and $\mathrm{t}$. In reporting "official" growth rates in the Table, I reestimate the official growth rate using this procedure, which lowers the official growth rate by .2 percent per annum. 
agricultual GDP by 1.7 percent and 2.5 percent, respectively. These adjustments are substantially less than those made by Summers and Heston version 5.6 which, for the period 1978-1992, when official GDP grew 8.9 percent per annum, reports an adjusted aggregate GDP growth rate of 5.6 percent. ${ }^{24}$ Figure I graphs the official and price index adjusted annual growth of GDP achieved since 1978. All of the downward adjustment in the growth rate brought about by the deflator substitution comes after 1986, with growth from 1986 to 1998 averaging 6.2 percent per annum, 3 percent less than the officially reported figure of 9.2 percent. In 1989, a year of economic retrenchment, GDP is now seen to have fallen by 5.2 percent, as opposed to the 4.0 percent positive growth reported in official figures. This provides some insight into the forces which precipitated the political unrest of that year.

Before concluding this section, I should note that it is possible to improve upon the threesector single deflation procedure suggested by Ruoen. While the Ex-Factory Price Index is a comprehensive industrial price index, it is an inappropriate deflator for construction (which is a part of secondary sector activity). Similarly, one might argue that the Service Price Index, a component of the CPI, is a poor indicator of price developments in wholesale and retail trade and transport, which make up almost half of service sector value added. Further, the output deflators suggested by Ruoen ignore changes in the relative prices of output and inputs. To this end, I have developed six-sector double-deflated estimates, as outlined in Table VI. I accept the official growth estimates of transport (as these are, purportedly, based upon real volume indices), substitute the retail price index for the bizarre ${ }^{25}$ official implicit output deflator of wholesale \& retail trade, and use the Service Price Index to deflate the remainder of service sector value added. For construction, I use data on the per square foot cost of state construction (1978-1990) and the new investment price index for construction activity activity (1990-1998) to derive an

\footnotetext{
${ }^{24}$ For the same period, my adjustments lower the growth of aggregate GDP to 7.7 percent per annum.

${ }^{25}$ See footnote 9 earlier above.
} 
alternative to the official implicit enterprise output deflator. ${ }^{26}$ Concluding with the substitution of the Farm and Sideline Price Index and the Ex-Factory Price Index for the primary sector and industry deflators, this alternative approach, when based upon single output-deflation, yields estimates of real output growth somewhat higher than those produced by Ruoen's procedure (Table VI). However, one can go further and, through the $6 \times 6$ use matrix of the 1987-1997 input output tables, double deflate the value added of each of the six sectors. After all of these adjustments, one arrives at estimated real, double deflated, value added growth rates slightly below those developed using Ruoen's simple single-deflated three sector approach. Consequently, to keep the analysis as transparent and reproducible as possible, in this paper I opt for Ruoen's suggested method, bearing in mind that a more nuanced and complicated approach yields virtually the same figures.

${ }^{26} \mathrm{My}$ index produces a fairly conservative measure of construction inflation. Appendix B compares it with potential alternatives. 


\section{Labour}

In the People's Republic there are two sources of data on the total and working population; the annual administrative and survey-based estimates reported in the China Statistical Yearbook and the tabulations of the occasional population censuses. In Table VII below I compare the figures found in the two sources. As the reader can see, the annual population estimates are quite close to those reported by the censuses. This is not surprising, since the former, although based on residence registration and sample surveys, are adjusted in accordance with the results of the latter. ${ }^{27}$ In regards to employment, however, there are large discrepancies both between the Census and the annual estimates and, within the annual estimates themselves, between the old series and its recent revision. These discrepancies require some explanation.

Under the plan, the SSB, using departmental reports and surveys, collected data on the "Total Labour Force of Society," which forms the basis for the "old" China Statistical Yearbook series reported in the Table. Referring to the working population, this series had a fairly stringent definition of employment requiring, for example, that young people in cities and towns with temporary employment ${ }^{28}$ earn, as a minimum, the wage level of local grade-one workers in order to be included in the series. ${ }^{29}$ In contrast, the Census definition of employment includes all those earning wage or management income, whether through permanent or temporary employment. ${ }^{30}$

${ }^{27}$ See CSY 1999 , p. 110 . I should note that the census population figures I report in the Table do not agree with the numbers reported in popular sources (e.g. the CSY), as I have adjusted the census population numbers to agree with the definition used in the annual series, i.e. adding in the members of the People's Liberation Army. The data presented in this and the following section, in addition to the CSY, draws upon the 1982 and 1990 Population Censuses, the 1987 and 19951 Percent Sample Surveys, and the annual issues of the China Population Statistics Yearbook.

${ }^{28}$ That is, while waiting to exercise their "right" to employment, participation in the military or further schooling.

${ }^{29}$ See Hsueh, Li and Liu [1993, p. 565] and Chen and Niu [1989, p. 203].

${ }^{30}$ Both censuses required that those with temporary employment worked 16 or more days in the month before the enumeration (1982 Census, pp. 606-607; 1990 Census, Vol. 4, p. 515) and restricted the working population to those aged 15 and above. 
Not surprisingly, the Census numbers tend to be greater. In 1997 the employment series reported in the China Statistical Yearbook was revised on the basis of the results of the annual Survey of Population Change. While the figures for earlier years were retained, the numbers from 1990 on rose substantially. As the reader can see, based upon the similarity of the estimates, the employment definition used by the population survey appears to correspond more closely with that used in the Census. ${ }^{31}$ The linking of the old data on the Labour Force of Society (prior to 1990) with the new labour force series (from 1990 on) in current official publications is regrettable, as it generates spurious labour force growth which, unfortunately, has been used by some economists as a measure of employment growth. While the Total Labour Force of Society is no longer reported as the official aggregate employment series, these data continue to be collected and can be inferred from the detailed tabulations of the China Statistical Yearbook. ${ }^{32} \mathrm{I}$ use these to extend the "old" series to 1998, as reported in the Table. However, I am not able to avoid a further discontinuity, introduced in 1998, when the definition of workers in urban enterprises was revised to include only those actually working and receiving income (as opposed to those who retained employment contracts, without actually working in the unit). This resulted in a substantial reduction in the estimated working population, particularly in manufacturing.

${ }^{31}$ The China Population Statistics Yearbook reports the population survey results, but gives no detail as to the underlying definitions. In any case, although the revised annual labour force series represent an adjustment "in accordance with the data obtained from the sample surveys on population changes" (CSY 1999, p. 133), they are not literally the population survey results, as the survey indicates even more working persons than are reported in the China Statistical Yearbook (compare China Population Statistics Yearbook 1998, p. 72 and CSY 1999, p. 133). I should also note that much of the revised industry and enterprise (e.g. state vs. collective) detail reported in the early 1990 s appear to be based upon simple "fudge factors", i.e. if the revised series indicated 9 percent additional aggregate employment, then the revised estimates of employment by industry or enterprise were increased, similarly, by 9 percent. As its name implies, the original emphasis of the Survey of Population Change concerned demographics, not the details of employment.

${ }^{32}$ While the summary tabulations on industry and enterprise employment in the China Statistical Yearbook are adjusted to reflect the revised totals, the tables on the detailed industry structure of employment continue to be based upon the old series which, consequently, can be extended by summing the relevant categories. 
As Table VII reports, all sources show labour force growth substantially exceeding the growth of the population. To explore the basis of this result, in Table VIII I report the participation rates by age group and sex implied by census and survey data. ${ }^{33}$ Between 1982 and 1990 , according to the Census, participation rates for the youngest age groups fell, while those for middle aged and elderly women rose slightly. The data of the 1997 Population Change Survey extend these trends. These developments are consistent with growing investment in education and the gradual aging of Communist-era women, who are likely to have had a greater history of lifetime market labour force participation than their predecessors. They are, however, largely offsetting. Of the increase in the overall participation rate from .52 to .57 between the Censuses of 1982 to 1990 , only 1.1 percent is due to changes in the age specific participation rates, with fully 98.9 percent attributable to the evolving age distribution of the population.

Since demographic trends play such an important role in explaining the rise in participation rates, it is important to examine these in greater detail. Table IX reports the distribution of the population of each sex by age group as reported in the two censuses and 1997 Survey, and, more importantly, compares the population of each Census/Survey with its surviving members (suitably aged) in the succeeding study. ${ }^{34}$ As shown, between 1982 and 1990 the cohort of 1982 infants grows, which is consistent with underreporting of births (to avoid official sanction), as does the cohort of 20-24 year old males, many of whom would have been in the military in 1982 (neither distribution includes active service military). ${ }^{35}$ Overall, however, the two Censuses are

${ }^{33}$ Prior to the 1982 Census, only fragmentary data on the characteristics of the workforce in particular sectors are available (e.g. Chen 1967, p. 484). The Labour Force of Society series, in particular, did not collect information on the characteristics of workers. Consequently, it is not possible to estimate labour force participation rates by age group prior to 1982 .

${ }^{34}$ I use the data on the population by single year of age, and then aggregate into the quinquennial age groups reported in the Table.

${ }^{35}$ While the 1990 Census reports (in separate tabulations) the age distribution of active service military, the 1982 Census does not. To keep the columns consistent, I report the ci vilian age distribution for both years. 
broadly consistent. In particular, the working age population does not miraculously expand. The same cannot be said for the 1997 Survey, which appears to undersample youths of 17-26 years of age (in 1997) and grossly oversample middle-aged women. One can correct for this, however, by "ageing" the 1990 Census population (using the annualized 1982-1990 age specific survival rates), and applying the 1997 Population Survey age specific participation rates to arrive at a synthetic 1997 working population.

Between 1982 and 1990, according to the Census, the working population grew 2.7 percent per annum. Comparing the 1997 synthetic working population with the 1990 Census, one finds that the working population grew 1.4 percent per annum during this period. Extending the 2.7 percent growth rate to the entire 1978-1990 period, and the 1.4 percent growth to the $1990-1998$ period, one derives an average estimated working population growth of 2.2 percent between 1978 and 1998. As can be seen from Table VIII earlier, this agrees, exactly, with the growth reported by the "old" Labour Force of Society employment series (particularly after it removed, in 1998 , absentia workers). In sum, working population growth of 2.2 percent per annum, in excess of the 1.3 percent rate of population growth, is completely consistent with reasonable participation and demographic trends and may be deemed fairly accurate.

To complete this section, I need to derive estimates of the growth of the working population in the non-agricultural sector alone. Table $\mathrm{X}$ below summarizes the distribution of the working population by economic sector, as reported in the Labour Force of Society data and the Census. The Labour Force of Society data indicate a substantial movement of labour out of agriculture into the industrial and service sectors of the economy. In contrast, the census data show an extraordinary stability in sectoral shares. Given the well-known explosion of rural industrial activity during the reform period, these data strain credulity. The shift of labour out of agriculture into the industrial sector is confirmed by the the industrial censuses of 1985 and 1995 which, as shown in Table XI, indicate industrial labour force growth which exceeds that reported in the data of the Total Labour Force of Society, 
The Chinese population censuses are unusual in that rather than ask the respondent to specify his area of industrial activity, they ask the respondent to provide the name of his place of work, which is then used to determine the industrial sector. Thus, the 1982 Census contains detailed instructions for enumerators on how the enterprise name should be recorded, even requiring, in the case of large enterprises, a precise specification of the department name. The 1990 Census provides similar instructions but, perhaps frustrated by the large number of respondents reporting "agriculture" in the earlier Census, emphasizes that peasants must report the name of their enterprise (but, still, not its industrial sector). In any case, the instructions then completely undermine the accuracy of the statistics by noting that for households which contract land, and operate as an independent economic unit, all working members of the household should report the main household product as the enterprise name. The confusion created by the use of a single question to collect two pieces of information, industry of employment and a record, with associated personal names, of each individual's place of work, is obvious. ${ }^{36}$ In contrast with the Census, the Total Labour Force of Society, as it is based partly on enterprise reports, is much better equipped, albeit not perfectly so, to track the movement of labour between sectors. $^{37}$

One can make use of a national income identity to verify the accuracy of the intersectoral transfer of labour reported in the Total Labour Force of Society data series. The share of labour in non-agricultural GDP equals the sum of worker wages divided by total value added:

(7) $\theta_{L_{N A}}=\frac{\sum_{i} w_{i} L_{i}}{Q_{N A}}=\frac{\sum_{i} w_{i} s_{i}}{Q_{N A}} L_{N A}$

${ }^{36}$ The statistical purpose served by collecting workplace names is mystifying, as this information cannot be meaningfully aggregated.

${ }^{37}$ I should note that the broader Census definition of employment cannot explain the difference between the two series. As shown in Table XI, the Census actually reports lower absolute industrial employment in 1990, despite the fact that its overall employment estimate substantially exceeds that reported in the Labour Force of Society series (Table VII earlier). 
where the index $\mathrm{i}$ denotes the various subsectors of non-agricultural GDP and $\mathrm{s}_{\mathrm{i}}$ their corresponding shares of total non-agricultural labour. From this, it follows that the growth of nonagricultural labour should equal the (ln) growth of nominal non-agricultural GDP, minus the growth of weighted wages, plus the growth of the share of labour. Table XII below presents the relevant data. Between 1978 and 1998 nominal non-agricultural GDP grew 16.1 percent per annum. Weighting the official series on the wages of staff and workers by detailed sector using the detailed employment distributions of the Labour Force of Society data, I find that weighted nominal non-agricultural wages grew 12.5 percent per annum. Finally, as will be seen in Section VI, the national accounts show the income share of non-agricultural labour rising 1.4 percent per annum. Together, these data imply a 5.0 percent annual growth in non-agricultural employment. The Labour Force of Society indicates growth of 4.5 percent per annum. Thus, if anything, this series may understate the growth of non-agricultural employment. ${ }^{38}$

In this paper I use the data series on the Total Labour Force of Society to measure the growth of labour input. As shown above, the overall growth of the working population in this series is perfectly consistent with reasonable demographic and participation data, while its nonagricultural component is, by the standards of the industrial surveys and national income and wage data, modestly conservative.

${ }^{38}$ Alternatively, one can interpret the data in Table $\mathrm{X}$ as indicating that the growth of nominal output is overstated by about .5 percent per annum. 


\section{Human Capital}

A proper measure of the growth of labour input should account for differentiation in the human capital of the workforce. Following Jorgenson et al (1987), I take labour input to be a translog index of differentiated labour types, with the growth of effective labour input between periods $\mathrm{t}-1$ and $\mathrm{t}$ given by:

(7) $\sum_{i} \ln \left\{\frac{L_{i}(t)}{L_{i}(t-1)}\right\}\left[\frac{\theta_{i}(t)+\theta_{i}(t-1)}{2}\right]$

where $L_{i}$ is labour of type $i$ and $\theta_{i}$ its share of total payments to labour. The difference between the growth of the effective labour force and the overall growth of the working population can be taken as the growth of "human capital." 39 To arrive at this measure, one needs data on the characteristics (age, education and sex) of workers and their relative incomes.

While the Labour Force of Society data series provides a reasonable measure of the overall growth of the labour force and its sectoral distribution, it does not contain any information on the characteristics of workers. To adjust for the changing characteristics of workers, one must turn to census and occasional survey data. Table XIII below summarizes the sex, educational and age characteristics of the working population, as indicated by the 1982 and 1990 Censuses, the 1987 and 1995 1\% Sample Population Surveys, and the 1997 Survey on Population Change. As the Table shows, the various censuses and surveys indicate a gradual rise in the proportion of female workers, aging of the labour force, and improvement in its educational attainment. In the pages below I examine the accuracy of these trends. To shorten the discussion, I focus on the changes from 1982 to 1990 (Census to Census) and 1990 to 1995 (Census to Survey), as I will use these

${ }^{39}$ Keeping in mind that, in a fashion common to all growth accounting measures of factor inputs, improvements in the efficiency of each like unit (which, in theoretical models are also termed "human capital") are bundled into the residual. 
two discrete growth periods to measure the growth of human capital during the reform period. ${ }^{40}$

The preceeding section established the reasonableness of the demographic and employment trends by sex and age present in the Chinese census data. Turning to the educational data, Table XIV below reports the distribution of educational attainment by age cohort in the aggregate Chinese population as recorded in the 1982 Census. The table then subtracts this distribution from that present in the (suitably aged) equivalent cohort in the 1990 census. While a rise in the educational attainment of young cohorts, who would still be pursing formal schooling, is to be expected, in the Chinese data improvements in educational attainment extend deeply into older age groups. Better educated persons are likely to have lower mortality rates (which will shift the educational distribution up as cohorts age) but, as the right hand side of the Table shows, this does not explain the Chinese data, where the absolute number of educated persons in older age cohorts rises from one census to the other!

The political campaigns of the Cultural Revolution (1966-1976) disrupted the lives of many in the People's Republic, preventing them from pursing formal education to the level they might otherwise have chosen. To compensate for this, the Chinese government provides equivalency exams which individuals, after self study or adult education, may take to increase their formal certification. ${ }^{41}$ Table XV below reports data from the 1995 1\% Population Survey on the share of those claiming tertiary or secondary educational attainment who achieved that standard through adult education. As shown, an extraordinarily large percentage of older age groups achieved their educational status through adult education courses. ${ }^{42}$ Data on the annual flow of

\footnotetext{
${ }^{40}$ I do not have access to data on the educational attainment of the total population for the 1997 Survey. As I need this information to generate a synthetic educational attainment (see below), I rely on the 1995 Survey instead.

${ }^{41}$ Both the 1982 and 1990 Census indicate explicitly that persons taking such exams may claim the corresponding formal attainment.

${ }^{42}$ Not surprisingly, younger age groups also avail themselves of the opportunity to achieve higher levels of certification through this channel.
} 
students in mainstream and adult education schools (Table XVI) confirm the relative importance of continuing education. These data also show, however, the inferior quality of adult education programmes, as these tend to be shorter, with a high ratio of graduates to students, and have much higher student-teacher ratios. While not all such graduates could claim mainstream equivalency, the mixing of mainstream and adult education in the Census data on improving educational attainment is clearly problematic, as the two types of certification would, most likely, command different market prices. To alleviate any concerns on this dimension, in the analysis below I develop a synthetic 1990 labour force, in which any improvement in the educational distribution of cohorts aged over 25 in 1982 , is disallowed. ${ }^{43}$

Turning next to the 1995 1\% Sample Population Survey, Table XVII ages the quinqennial age cohorts of the 1990 census and compares the resulting distribution to the population recorded by the 1995 Survey. Once again, the cohort of 1990 infants expands, reflecting the underreporting of births. More worrisome, however, is the underreporting of youths and oversampling of middle aged men and, particularly, woman, patterns which, as discussed in the preceeding section, appear in the 1997 Population Survey as well. ${ }^{44}$ To correct for changes in the sampling distribution, in the analysis below I construct a synthetic 1995 working population by aging the 1990 age cohorts (using the 1982-1990 annual survival rates) and then applying the age $\mathrm{x}$ sex labour force participation rates recorded by the 1995 Sample Survey. A comparison of the cohort specific distribution of educational attainment indicates, as was the case in the 1982-1990 period, a systematic rise in the educational attainment of older cohorts (Table XVII). To alleviate concerns on this dimension, I construct an alternative synthetic estimate in which I disallow all improvements in the educational attainment of cohorts aged over 25 in 1990.

\footnotetext{
${ }^{43}$ I allow younger cohorts to improve their attainment, as these could still have been pursuing formal schooling between 1982 and 1990.

${ }^{44}$ This appears to be a characteristic of the 1990s Surveys. The 1987 Survey, in contrast, is quite consistent with the age distribution of the 1982 and 1990 Censuses.
} 
Table XVIII below summarizes my measures of the sex, age and educational composition of the workforce. The baseline measure accepts the 1982 and 1990 census data and estimates the age distribution of the 1995 population by ageing the 1990 Census population using the annualized 1982-1990 survival rates, using the 1995 Survey to determine the participation rates and educational characteristics of each quinqennial age cohort. The alternative measure disallows any improvement in the educational attainment of cohorts aged over 25 between 1982 and 1990 , but uses the age $\mathrm{x}$ sex $\mathrm{x}$ education participation rates of the 1990 Census to determine the labour force participation of the resulting educationally-demoted population. The alternative 1990 population is then aged further from 1990 to 1995, disallowing any improvements in the educational attainment of cohorts aged over 25 in 1990, and uses the age $\mathrm{x}$ sex $\mathrm{x}$ education participation rates of the 1995 Survey to determine labour force participation of each group in that year. The resulting marginal distributions are summarized in the Table.

Published data on the relative labour incomes of Chinese workers by worker characteristic are, basically, non-existent. However, the SSB's Urban Household Survey has a history of asking for the characteristics and individual labour income of the members of the survey households. I have been able to acquire the survey files for the years 1986-1992. I supplement these with the files of the Household Survey (urban and rural) executed in 1988 and 1995 by the Chinese Academy of Social Sciences, which contain similar data. ${ }^{45}$ While the surveys cover a large number of provinces and cities, they are by no means a balanced sample (e.g. some provinces are not represented, while the samples, both rural and urban, are heavily biased toward better educated households). The survey responses also have substantial coding errors and internal inconsistencies, with, for example, non-labour market participants reporting positive earnings. I narrow the samples considerably by requiring that the respondents consistently, across a variety of questions, identify themselves as working employees in the non-agricultural sector. The final

\footnotetext{
${ }^{45}$ These data can be purchased from the Universities Service Centre, Chinese University of Hong Kong.
} 
sample size is 222,281 observations. I regress the ln wage of each individual on age, sex and education dummies, these dummies interacted with time, and a dummy for each survey (year or urban/rural), the latter controlling for overall wage growth and differences in the definition of income used by the different surveys. The R-squared of the regression is .83 , with a partial R-squared, netting out the survey dummies, of .16.

Table XIX reports the estimated education, age and sex income profiles in the People's Republic, and contrasts these with $1980 / 81$ estimates for the newly industrializing countries. ${ }^{46}$ In China, wages rise with educational attainment, but at a slower rate than in the other economies. Similarly, for given age and educational characteristics, women earn lower wages, but considerably less so than in the NICs. The age income profile in most of the NICs follows an inverted-U pattern, reflecting, perhaps, the competing forces of experience, vintage effects in human capital, and physical ageing. In contrast, experience (or seniority) in the People's Republic confers permanent income advantages. It is unclear whether these differences reflect genuine differences in relative marginal products, or Socialist wage distortions aimed at promoting income equality and protecting the elderly. The Chinese trend coefficients argue in favour of the latter interpretation, as reform appears to have led to a declining relative female wage, rapidly rising premium for tertiary educated workers, and sharp movement toward an inverted-U age profile (with elderly workers earning substantially lower incomes). Nevertheless, rather than make ad hoc adjustments to the Chinese data, I accept them as they are, using the relative wage estimates to weight

${ }^{46}$ The Taiwanese profile is estimated using the individual labour income of nonagricultural wage earners (excluding self employed and unpaid workers) in the 1980 Survey of Personal Income Distribution. For Hong Kong, Singapore and South Korea I do not have individual files, and base my estimates upon Census data and wage surveys (see Young 1995). For these economies I regress my estimates of the average labour incomes of each sex $\mathrm{X}$ age $\mathrm{X}$ education cell on the appropriate dummies. I focus on 1980 on the grounds that the technology and factor supplies in use in these economies at that time might, heroically, approximate those at play in China during the 1980 s and 1990 s. I should note that the Korean data refer primarily to the manufacturing sector. 
the changing composition of the workforce. ${ }^{47}$

Table XX below reports my estimates of the average growth of human capital in the People's Republic during the reform period. ${ }^{48}$ The baseline working population, using Chinese income weights, suggests a growth rate of 1.1 percent per annum. This is not substantially different than the estimates one arrives at using the original data (which, in 1995, introduces older workers and more females) or my alternative estimates (disallowing educational improvements for those over 25). The use of NIC income weights, with their steeper profiles, would, on average, raise these estimates slightly. As explained in the previous Section, I reject the Census data on the distribution of the working population across sectors as being highly unrealistic. Consequently, I also reject the Census detail on the characteristics of workers by sector, taking the data on the improvement of the human capital of all workers as being a more accurate reflection of overall and sectoral trends. ${ }^{49}$ Nevertheless, for the reader's information, I report in the Table the growth of human capital calculated using data on the characteristics of non-agricultural

${ }^{47}$ I use the estimates for 1990 and 1995 to weight the working population of those years, and the point estimate for 1986 to weight the working population of 1982 , i.e. I do not extrapolate the wage trends out of sample.

${ }^{48}$ I calculate the growth rate separately for the 1982-1990 and 1990-1995 periods and arrive at an average growth rate for $1978-1998$ by combining these with $12 / 8$ weights (i.e. assuming that these rates held throughout 1978-1990 and 1990-1998, respectively).

${ }^{49}$ Focusing on the characteristics of the total working population also allows me, as shown above, to evaluate the overall accuracy of the data and develop alternative estimates. This is not possible at the sectoral level.

I should note that the $19951 \%$ Sample Survey, like the Census, shows virtually no transfer of labour out of agriculture. This Survey continues the tradition of trying to use one question to gather both industrial and personal information. Thus, following the disappointing results of the previous Censuses, the Survey instructions excoriate peasants not to report "agriculture", emphasize that villagers with stable employment in enterprises should report the enterprise as their place of work, and even provide an area (within the item) for detail on the actual industry of employment, while to continuing to make the recording of the enterprise (and sub-department) name the main objective of the questionnaire including, this time, a special emphasis on determining the exact legal status of the enterprise. As shown above, the Survey's overall sample is biased and needs to be adjusted, so I do not include it in Section II's discussion of the intersectoral allocation of labour. Nevertheless, since it shares a questionnaire very similar to that of the Census, it is not surprising it yields similar results. 
workers alone. This lowers the growth rate somewhat when calculated using Chinese income weights, but has a negligible impact on the estimates derived with the NIC income weights. The NIC income weights place a greater premium on tertiary education, which contributes more to the rise in the human capital of non-agricultural workers, as reported in these sources.

In this paper I take the growth of human capital in the non-agricultural sector of the Chinese economy between 1978 and 1998 to be 1.1 percent per annum. As Table XX clearly shows, both slightly lower and moderately higher estimates are plausible, but all estimates are tolerably concentrated around a value of 1.1 percent. 


\section{Physical Capital}

Figure $\amalg$ below graphs the ratio of inventory accumulation and gross fixed capital formation to nominal GDP in the People's Republic. In my experience, the "changes in stocks" figures reported in the national accounts of developing countries are frequently a residual, fabricated, item used to conceal large discrepancies between the production and expenditure sides of the accounts. In addition, the proper measurement of inventory changes, including the adjustment for differences between current valuations and accounting conventions, is technically more challenging than the measurement of the flow value of investment in fixed capital. Finally, in the context of the People's Republic, considering the unsold inventories of state enterprises as a productive element of the capital stock would seem to be an egregious error. For these reasons, in this study, as in past work [Young 1995], I exclude inventories from my measure of the capital stock, and focus on gross fixed capital formation alone.

As emphasized in the Introduction, this paper focuses on the non-agricultural sector of the Chinese economy, using reproducible capital, alone, as a measure of the capital stock. Although the published Chinese national accounts do not provide information on the sectoral distribution of gross fixed capital formation, the provincial accounts do. For the period 1978 to 1995 , Hsueh and $\mathrm{Li}$ [1999] report the sectoral distribution of gross fixed capital formation in 26 provinces, ${ }^{50}$ accounting for an average of 78 percent of the annual value of national gross fixed capital formation. I assume that aggregate gross fixed capital formation during this time period has the same agricultural/non-agricultural distribution, and extend the series forward by assuming that investment shares in 1996 and 1997 were the same as in 1995. For the period 1952-1977, I draw on data in the CSY on the sectoral distribution of the gross fixed capital formation of state owned units, which accounted for an average of 57 percent of the annual value of national gross fixed capital formation during this period, to allocate the overall national fixed capital formation

\footnotetext{
${ }^{50}$ All provinces other than Jiangxi, Guangdong, Hainan and Tibet.
} 
between the agricultural and non-agricultural sectors of the economy. As shown in Figure III, the proportion of state enterprise investment in agriculture is well below the provincial average (which includes the activity of collective enterprises), so my use of state enterprise investment to allocate investment during the period 1952-1977 introduces a discontinuity in 1978, when, as I switch to the provincial sample, the proportion of investment in agriculture jumps. This introduces a slight downward bias into my estimate of capital growth in the non-agricultural sector.

With a measure of non-agricultural investment in hand, it is necessary to derive an appropriate fixed capital formation deflator. The official deflator for GFCF is presumably an inappropriate choice, as it is relies upon enterprise output deflators ${ }^{51}$ and is, consequently, likely to be characterized by the same understatement of inflation that plagues the People's Republic's production estimates. An alternative independent price index is available in the form of the Price Index of Investment, but this index has only been available since 1990, which does not provide a sufficiently long time series. A third approach is possible, exploiting the national income accounting identity equating the GDP deflator calculated from the production accounts with the same deflator calculated from the expenditure accounts. Alternative price indices for the noncapital components of final expenditure are available, or easily constructed. Combining these with the revised production deflators calculated in Section II earlier, one can construct an implicit GFCF deflator as part of the process of developing an internally consistent set of production and expenditure accounts.

Table XXI summarizes the growth of the expenditure accounts deflators, official and alternative. While the standard Chinese statistical sources never report the deflators (or real growth) of the expenditure components of GDP, Hsueh and Li provide some such information, for the period 1978-1995, in their comprehensive (1999) review of Chinese national income accounting methodology. At the top of the Table I list the growth of the implicit GDP deflator,

${ }^{51}$ Most of capital formation is construction (see below), which is deflated using the implicit enterprise output deflator for the construction industry (Hsueh and $\mathrm{Li}$, p. 148). 
calculated from the production side of the accounts, ${ }^{52}$ along with my alternative estimates. The expenditure share weighted average of the growth of the component deflators should equal this number. To begin with the simplest item, private consumption expenditures, the Chinese national accounts deflate these using various components of the consumer price index, plus the implicit enterprise deflator for construction. ${ }^{53}$ I replace the official deflators with the Consumer Price Index, rural and urban, ${ }^{54}$ which report very similar inflation rates.

Turning to government consumption, the official (Hsueh and Li 1999, p. 148) methodology is to deflate government employee salaries by the consumption basket of those workers (!), and the goods and service components of government purchases using the retail and service price indices. Not only is this approach grossly incorrect, it is also, apparently, not implemented. At 5.6 percent per annum, the growth of the official government expenditure deflator is well below the growth of the retail price index, the consumer price indices, or the (CPI) service price index. The extremely slow growth of this deflator plays an important role in offsetting the high inflation recorded in other components of the expenditure accounts, thereby bringing the official expenditure accounts in line with the production side. To replace the official deflator, I calculate the share of employee salaries (taken as the value of government output on the production side of the accounts) in government expenditures, and arbitrarily divide the remainder, about $80 \%$ of the total, equally between goods and services purchases. I then use these weights to construct an expenditure deflator by combining the growth of the average wage of staff and workers in gov-

${ }^{52}$ This is not, precisely, the official deflator as I replace the official Paasche weights with Tornqvist weights, which raises the growth of the deflator .2 percent per annum (see footnote 23 in Section II)

${ }^{53}$ Peculiarly, the consumption accounts include an adjustment for the depreciation of private housing [Hsueh and Li, p. 147].

${ }^{54}$ The rural CPI is only available from 1984 on. I extend it back to 1978 using the growth of the urban CPI. 
ernment and party agencies and social organizations ${ }^{55}$ with the growth of the retail and services price indices.

With regards to inventories, the official deflator divides inventory accumulation into agricultural, industrial and commercial components and deflates these using price indices such as the farm and sideline products procurement price index. I adopt a similar approach, using the detailed capital formation accounts of the 26 province sample noted earlier to separate inventory accumulation into primary, secondary and tertiary sectors, which I then deflate using the farm and sideline products, ex-factory and retail price indices, respectively. Reassuringly, my measure of overall inventory inflation is close to the official estimate. Finally, for exports and imports no official deflator, that I know of, has been circulated. From earlier work [Young 1999], I have quantity and value data on Hong Kong's trade with the Mainland during the period 1984-1996 broken down into 823 consistent import and 899 consistent export product categories. I use these to construct a weighted unit value index for that period, and extend the analysis to the years 1996-1998 and 1981-1984 using data on the values and quantities of principal import and export products published in the CSY. ${ }^{56}$ For the period 1978-1981, I use the retail price index to deflate both imports and exports. ${ }^{57}$ The import and export price indices show about 9 percent inflation per annum, although the movement in dollar prices is considerably less, as the effective yuan/dollar exchange rate ${ }^{58}$ depreciates 7.9 percent per annum.

\footnotetext{
${ }^{55}$ Less a 1.1 percent per annum adjustment to reflect the changing characteristics of workers, as per my analysis of Section IV earlier.

${ }^{56}$ The Hong Kong data account for an average of 30 and 19 percent of the value of Chinese exports and imports, respectively, while the CSY data cover about $2 / 3$ of the total value of exports and imports in 1981-1984, and 1/3 of their value in 1996-1998. The CSY data only contains about 150 export and 70 import categories. Consequently, for the period 1984-1996 I rely on the Hong Kong data, which, despite its smaller share of the value of trade, contains much finer product detail.

${ }^{57}$ I hope to improve on this, with further unit value data, in a later draft.

${ }^{58}$ Computed by dividing the value of exports and imports in yuan by their value in dollars, as reported in the CSY.
} 
Turning, finally, to fixed capital formation, the official deflator increases 7.0 percent per annum between 1978 and 1995. Taking as given my estimates for the other elements of the expenditure and production accounts, I produce an alternative GFCF deflator, as a balancing residual, which grows 10.1 percent per annum during the same period. It is interesting to note that the official deflator, which relies heavily on the enterprise deflators in secondary industry, shows about .7 of the inflation recorded in the alternative GFCF price index, which is close to the estimates, in Section II, of the bias in the secondary deflators. As another consistency check, I note that between 1978 and 1998 the machine building industry component of the ex-factory price index increases 4.3 percent per annum, while the unit cost of construction activity, calculated from data on state and overall construction costs (see Section II and Appendix B) grows 10.6 percent per annum. Weighting these by the annual investment shares of machinery and construction (with construction accounting for about .7 on average), ${ }^{59}$ one arrives at an annual GFCF inflation rate of 8.9 percent for the $1978-1998$ period. This compares, very favourably, with the 8.8 percent 1978 -1998 GFCF inflation rate calculated, as a residual, in Table XXI. In sum, three independent ways of calculating the average growth of the GFCF deflator all yield highly similar estimates.

Figure IV below graphs the official and alternative GFCF deflators. For the period 1978-1998, I take as the alternative deflator the residual inflation calculated above. However, I lack the price indices to reproduce this analysis for 1952 through 1977 . Consequently, for that period, I assume that officially recorded GFCF inflation is .7 of actual. As shown, the plan period was one of relative price stability so that the notion that the official deflator is any multiple of the underlying inflation rate amounts, in effect, to the assumption of a constant capital

${ }^{59}$ I use the CSY data on fixed asset investment by use of funds (e.g. CSY 1999, Table 6-1). These data include a category "other", which encompasses not-capital costs such as training, product research, etc. I remove these, focusing on equipment and construction alone. According to Hsueh and $\mathrm{Li}(1999$, p. ) many, but not all (e.g. research), of these elements are removed in producing the national accounts estimates of GFCF. 
deflator. With these deflators in hand, I calculate the capital stock using the perpetual inventory method and a 6 percent depreciation rate. I initiate the capital stock in 1952 by assuming that the real investment growth recorded in the first 5 years of the data extends into the infinite past. ${ }^{60}$ With 26 years of data before the beginning of the analysis, the initial capital stock is fairly irrelevant, and any assumption will do equally well.

Table XXII summarizes my estimates of the growth of the capital stock. Using the official deflators, the non-agricultural capital stock increases 9.2 percent per annum. With the alternative deflator it grows only 7.7 percent. Despite a fairly constant investment to GDP ratio during the reform period, both the official and alternative data indicate a falling non-agricultural capitaloutput ratio, driven by an almost one percent annual increase in the relative price of capital. ${ }^{61}$ As noted above, machinery prices are rising relatively slowly, but the growth of the price of construction (whether measured officially or using alternative price indices) is very high, and construction dominates fixed capital formation.

${ }^{60}$ Specifically, the capital stock in 1952 is given by real investment in 1952 divided by .06 (the depreciation rate) plus the average annual growth of real investment between 1952 and 1957.

${ }^{61}$ Between 1978 and 1998 the official and alternative non-agricultural GDP deflators grow 5.5 and 7.9 percent per annum, respectively, while the corresponding capital deflators increase 6.3 and 8.8 percent per annum. I should note that, as described earlier, Hsueh and Li's data on the official GFCF deflator ends in 1995. To compute the "official" estimates, I extend the deflator to 1998 using the growth of the Price Index of Investment. 


\section{Factor Income Shares}

Table XXIII below reports the ratio of compensation of employees to GDP at factor cost in the People's Republic, estimated using data from the national accounts and input-output tables. As the reader can see, the figures produced by the two sources are in broad agreement, although the data in the input-output tables are quite volatile. The overall economy-wide share of labour appears to be about .6, while in the non-agricultural sector it averages slightly below .5. At first glance, these figures appear to be somewhat low. As shown in Table XXIV, in my 1995 analysis of total factor productivity growth in the newly industrialized countries, for example, I used (adjusted) shares of labour in non-agricultural activity on the order of $.6, .7$, and even .75 . Only in the case of Singapore did my estimate of the share of labour in non-agricultural activity fall as low as .5. These figures, however, involve a modification of the underlying data. In Table XXIV I also report the actual share of labour, i.e. compensation of employees divided by GDP at factor cost, recorded by the national accounts and input-output tables of the NICs. At this level, the NICs are quite similar to the People's Republic, and to each other as well, with nonagricultural labour shares of .5 appearing to be the norm, rather than the exception. To understand the adjustments I made, why these were so minimal for Singapore and so substantial for the other economies, and why no such adjustments are necessary for China, requires some explanation of the methods of the national accounts.

While the standard precepts of national income accounting require the imputation of some sources of income (e.g. the implicit rental on owner-occupied housing), they explicitly exclude such imputations in the case of labour. "Compensation of employees", as defined in the System of National Accounts, includes all wages, salaries, and supplements earned by employees, the value of any income in kind (lodging, etc) they receive from their employers, and employer payments for their social or private pensions. The implicit labour income of proprietors, unpaid family members and the self-employed is supposed to be captured, along with elements of the return to capital, under items such as "Income from unincorporated enterprises" [United Nations 
1953]. Since compensation of employees is restricted to employees, a natural adjustment suggests itself: Impute to each non-employee worker an hourly wage equal to the average hourly wage of employees with the same age, sex and educational characteristics. Aggregating across employee and non-employee hours of work then provides an estimate of total explicit and implicit labour income. Multiplying the unadjusted share of labour (compensation of employees over GDP at factor cost) in the national accounts by one plus the ratio of implicit to explicit labour income yields an estimate of the "true" share of labour. ${ }^{62}$ This is the procedure I used in my 1995 analysis of the NICs. Unfortunately, it systematically overstates the share of labour.

While national income accountants are not supposed to impute labour income to nonemployees, in practice they do so, albeit unintentionally. To understand why, the reader might consider how he or she would go about constructing an estimate of total compensation of employees in a data poor developing country. The cost shares of large incorporated enterprises are somewhat known, from sectoral surveys or tax records. In the case of small unincorporated enterprises, however, officials have little data, as the costs of data collection and monitoring limit the information, where it exists, to the most basic items, e.g. declared output. Bereft of data, the national income accountant can either assume that (a) unincorporated enterprises pay no compensation of employees; or (b) that the share of compensation of employees in their total output is the same as that appearing in larger incorporated enterprises. The latter assumption is more palatable, and appears to be used in practice. ${ }^{63}$ Since the share of unpaid workers in small firms is substantially higher than in large firms, this procedure automatically imputes labour income to the unpaid workers of small firms. In Table XXV below I list my 1995 estimates of the adjusted

${ }^{62}$ One cannot use the estimates of implicit and explicit labour income drawn from labour force survey and census data directly, as these typically do not include income in kind or pensions. Multiplying by the national accounts estimate of compensation of employees scales for these factors, as well as adjusting for any inconsistency between the overall level of employee income reported by workers and firms.

${ }^{63}$ See, for example, Republic of China [1997, pp. 235-239]. 
share of labour in sectors such as wholesale and retail trade and personal, social and community services, which have large numbers of non-employee workers. Imputing an implicit income to unpaid workers frequently results in a labour share exceeding one, as payments to labour more than exhaust the total output of the sector. ${ }^{64}$ This is precisely what would arise if one double counted the implicit income of unpaid workers. ${ }^{65}$

The compensation of employees data reported by national income accountants lie somewhere between the accounting precepts of the System of National Accounts and a measure involving a full imputation of the implicit labour income of unpaid workers. As a lower labour share will typically yield lower estimates of total factor productivity growth, to avoid cricitism on this dimension in Young 1995 I assumed that the national accounts followed, precisely, the conventions of the SNA and made a full adjustment for the implicit income of unpaid workers. The difference between Singapore and the other economies does not lie in the national income data, but rather in the fact that Singapore has far fewer unpaid workers operating in small family run enterprises. While my labour share estimates for Singapore are often criticized as being too low, it is more likely the case that, if anything, the estimates for the other economies are too high.

In the People's Republic, self employment is fairly rare. ${ }^{66}$ Moreover, the Chinese national accounts impute labour income to the self-employed, assuming that where self-employment is found (e.g. industry and construction), all income is labour income, and going so far as to con-

${ }^{64}$ The trends in the share of labour derive from the trends in the share of self-employed workers (falling in wholesale \& retail trade and rising in community, social \& personal services) as the unadjusted national accounts estimates of compensation of employees over GDP at factor cost are fairly constant.

${ }^{65}$ In a similar vein, Denison [1979, appendix G] found that business income (net of labour and material payments) in unincorporated enterprises in the United States was insufficient to cover an implicit labour and capital income equal to that of business sector employees and incorporated enterprise capital.

${ }^{66}$ According to the CSY 1999 (Table 5-4) self-employed individuals accounted for only 3 percent of the working population in 1990. This figure rises to 9 percent by 1998 . 
clude that the entire output of some sectors, e.g. personal and social services, contains no capital income component whatsoever, allocating all of the output of the sector between compensation of employees and depreciation. ${ }^{67}$ Consequently, there is no reason to modify the reported Chinese estimates of the share of labour. The share of labour in the non-agricultural economy in China is similar to that reported in other economies. Once adjustment is made for unpaid workers, the ratios of other economies are higher, which may or may not reflect an overstatement. In either case, given the methodology of the Chinese national accounts and the small number of self-employed in that economy, this fact provides no basis on which to modify the Chinese estimates. In this paper I use the average share of labour reported in the Chinese national accounts, in preference over the more volatile figures of the input-output tables.

${ }^{67}$ See Hsueh and Li 1999, pp. 111, 114-115 \& 123. 


\section{Total Factor Productivity Growth}

Table XXVI summarizes this paper's deconstruction of Chinese growth during the reform period. Using official data, the growth of output per capita, at 7.8 percent per annum, is unprecedented. If one substitutes the SSB's own price indices for its GDP deflators, the growth of output per capita is reduced to 6.1 percent, an extraordinary, but not unheard of, achievement. From here, the usual factors, present in other high growth economies, take over. Rising participation rates lower the growth of output per worker to 5.2 percent. Removing the agricultural sector raises the growth of GDP, but the growth of employment rises even further, lowering the growth of labour productivity to 3.6 percent. Accounting for the ageing and improving educational attainment of the workforce then brings this number down to 2.6 percent. The movement from 7.8 percent to 2.6 percent summarizes, in full, the main result of this paper. A few simple adjustments reduce the Chinese growth experience to a reasonable and comprehensible number.

Table XXVI also presents, as an afterthought, the growth of the output-capital ratio and total factor productivity. The growth of total factor productivity is a moderate, but respectable, 1.4 percent per annum. As there is no capital-deepening (in fact, the opposite) this result, conveniently, reemphasizes a point $\mathrm{I}$ have made repeatedly in previous papers: ${ }^{68}$ Labour-deepening (the rise in participation rates, transfer of labour out of agriculture, and improvements in educational attainment) and not capital-deepening is the key force explaining the extraordinary improvements in per capita living standards, in the presence of moderate total factor productivity growth, achieved by the high growth economies of East Asia.

The total factor productivity estimates of this paper should not, by any means, be taken as definitive. As Table XXVI shows, if one merely accepts the official GDP deflators, but keeps all other elements of the analysis unchanged, the growth of total factor productivity jumps to 3.0 percent. Beyond this, an impressive range of estimates is possible. A quick and dirty optimist

\footnotetext{
${ }^{68}$ See Young 1995, 1994 and even 1992 (p. 62).
} 
(Dr. Pangloss) might focus on the official (Laspeyres) growth of aggregate output per capita, denying the improvements in participation rates, ignoring changes in the composition of the workforce, and avoiding the difficult question of the validity of GFCF as a measure of the agricultural capital stock, ${ }^{69}$ assume a constant capital-output ratio and a .7 labour share (in line with the developed world), to produce a total factor productivity growth estimate of 5.6 percent per annum. At the other extreme, the data mining pessimist (Dr. Doom) might take my estimates as a baseline, but lower the growth of nominal output by 1 percent (to correct for exaggeration), use the current official series on employment (with its discontinuity in 1990), and weight the growth of human capital using Singaporean relative wages in 1980, to produce a non-agricultural total factor productivity growth estimate of -0.4 percent per annum. These parodies highlight the ease with which one can raise or lower estimates of total factor productivity growth. Hopefully, the reader can make use of the lengthy discussion of data in this paper to adjust the estimates presented in Table XXVI and attach to them the appropriate standard error.

${ }^{69}$ Positions frequently taken, explicitly or implicitly, in studies of total factor productivity. 


\section{Conclusion}

Having pressed through countless pages of dry data analysis, the reader should, arguably, be rewarded with some free ranging interpretation and speculation. The finding of moderate non-agricultural labour and total factor productivity growth can be viewed as either positive or negative. On the one hand, when contrasted with the experience of other reforming economies, sustained 2.6 percent labour productivity growth can be seen as nothing short of miraculous. On the other hand, given that the estimates presented in this paper are by no means the lowest possi$\mathrm{ble}^{70}$, and given the presumed inefficiency of central planning, one might have expected greater gains in a "successfully" reforming economy. In this regard, moderate productivity growth might be seen as reflecting enduring problems, such as the failure to reform state enterprises and the inefficiencies introduced by local government intervention in industrial production and trade. Both interpretations are valid, as the Chinese glass is, clearly, both half full and half empty.

Like many magicians and alchemists, this paper buries its trickery in the setting of the stage. Excluding agriculture, at the very beginning, from the analysis incorporates the transfer of labour out of that sector as an input, while excluding agricultural total factor productivity growth and the efficiency gains brought about by movement of labour from the measurement of output. The sustained growth of agricultural output during the reform period, in light of its rapidly declining share of the labour force, is a testament to the misguided nature of plan policies which kept the peasantry tied up in agriculture, by restricting rural-urban migration and limiting the development of rural non-agricultural activity, while saddling it with inefficient and alien organizational structures. The reversal of these policies may be one of the greatest, and easiest, achievements of the reforms, although agriculture remains distorted in many respects. ${ }^{71} \mathrm{~A}$ proper analysis of the agricultural sector, lying well beyond the abilities of the techniques used in

\footnotetext{
${ }^{70}$ In particular, there is no adjustment for the exaggeration of nominal growth.

${ }^{71}$ E.g. with local procurement and price controls.
} 
this paper, might find rapid productivity growth in that sector and large gains from the release of its pent up "surplus" labour.

Along with rising participation rates, educational attainment, and capital-investment, the transfer of labour out of agriculture, whether driven by productivity growth in that sector or the equalization of labour's marginal product with other sectors of the economy, has played an important role in the growth of economies such as Korea and Taiwan. It plays an equally significant role in fueling the growth of the People's Republic. Despite the popular academic emphasis on industry and exports, a deeper understanding of the success of the world's most rapidly growing economies may lie in that most fundamental of development topics: agriculture, land and the peasant. 


\section{Bibiliography}

Chan, Kam Wing. "Urbanization and Rural-Urban Migration in China since 1982," Modern China Vol. 20, No. 3 (July 1994), pp. 243-281.

Chen, Dong, and Zhili Niu, eds, Practical Manual on Economic Statistics of China (Zhongguo Tongji Shivong Daquan) (Beijing: China People's University Publishers, 1989).

Chen, Nai-Ruenn, Chinese Economic Statistics: A Handbook for Mainland China (Chicago: Aldine Publishing Company, 1967).

Denison, Edward F., Accounting for Slower Economic Growth: The United States in the 1970s (Washington D.C.: The Brookings Institution, 1979).

Hsueh, Tien-tung, and Qiang Li, eds, China's National Income, 1952-1995 (Boulder: Westview Press, 1999).

Hsueh, Tien-tung, Qiang Li and Shucheng Liu, eds, China's Provincial Statistics 1949-1989 (Boulder: Westview Press, 1993).

Jorgenson, Dale W., Frank M. Gollop and Barbara M. Fraumeni, Productivity and U.S. Economic Growth (Cambridge, MA: Harvard University Press, 1987).

Loehlin, John C., Latent Variable Models, 3rd ed. (New Jersey: Lawrence Erlbaum Associates, 1998).

People's Republic of China, State Statistical Bureau, China Population Statistics Yearbook (Zhongguo Renkou Tongji Nianjian) (Beijing: China Statistical Publishing House, annual issues).

China Statistical Yearbook (Zhongguo Tongji Nianjian) (Beijing: China Statistical Publishing House, annual issues).

Tabulations of China $1 \%$ Population Sample Survev (Zhongguo 1987 Nian 1\% Renkou Chouvang Diaocha Ziliao) (Beijing: China Statistica Publishing House, 1988).

,Tabulation on the 1990 Population Census of the People's Republic of China (Zhongguo 1990 Nian Renkou Tongii Ziliao) (Beijing: China Statistical Publishing House, 1993).

, 1982 Population Census of China (Zhongguo 1982 Nian Renkou Pucha Ziliao) (Beijing: China Statistical Publishing House.

1995 Nian Ouanguo 1\% Renkou Chouvang Diaocha Ziliao (Beijing: China Statistical Publishing House).

Republic of China, Directorate-General of Budget, Accounting and Statistics, National Income in Taiwan Area of the Republic of China 1997.

Ruoen, Ren, "China's Economic Performance in International Perspective." O.E.C.D. Development Centre manuscript, October 1995. 
Summers, Robert and Alan Heston, "Append 5.6: Appendix TABLE OF CONTENTS for a Space-Time System of National Accounts aka Penn World Table 5.6", text file accompanying Penn World Tables Version 5.6, December 1994.

United Nations, Department of Economic Affairs, A System of National Accounts and Supporting Tables (New York: United Nations, 1953).

Woo, Wing Thye, "Chinese Economic Growth: Sources and Prospects", Manuscript, University of California, Davis, October 1995.

Young, Alwyn, "A Tale of Two Cities: Factor Accumulation and Technical Change in Hong Kong and Singapore", in Olivier J. Blanchard and Stanley Fischer, eds., NBER Macroeconomics Annual 1992, Cambridge, MA: MIT Press, 1992.

"Lessons from the East Asian NICS: A Contrarian View", European Economic Review 38 (1994): 964-973.

, "The Tyranny of Numbers: Confronting the Statistical Realities of the East Asian Growth Experience", Quarterly Journal of Economics (August 1995): 641-680.

, "Transport, Processing and Information: Value Added and the Circuitous Movement of Goods", Manuscript, University of Chicago, May 1999. 


\section{Appendix A: Remaining Parameters of the Latent Variable Models}

Table A-I lists the remaining parameters of the latent variable models estimated in Section $\Pi$ of the paper. To ensure that the covariance matrices are positive definite, I use a Cholesky factorization to estimate the covariance matrix of the latent inflation rates, and decompose the variance of the orthogonal price specific errors into the product of diagonal standard error matrices. In sum, I estimate the following covariance matrix:

(3) $\Sigma_{\mathbf{x}}=\mathbf{B C C}^{\prime} \mathbf{B}^{\prime}+\mathbf{P P}^{\prime}$

where $\mathbf{C}$ is the lower-triangular Cholesky factorization and $\mathbf{P}$ is a diagonal matrix of the standard errors of the price specific errors. In the case of the nominal shock model, the Cholesky factorization refers to the real shocks $\mathrm{v}_{\mathrm{it}}$, while $\sigma_{\pi}$ measures the standard error of the nominal shock.

Table A-I: Remaining Parameters of Latent Variable Models

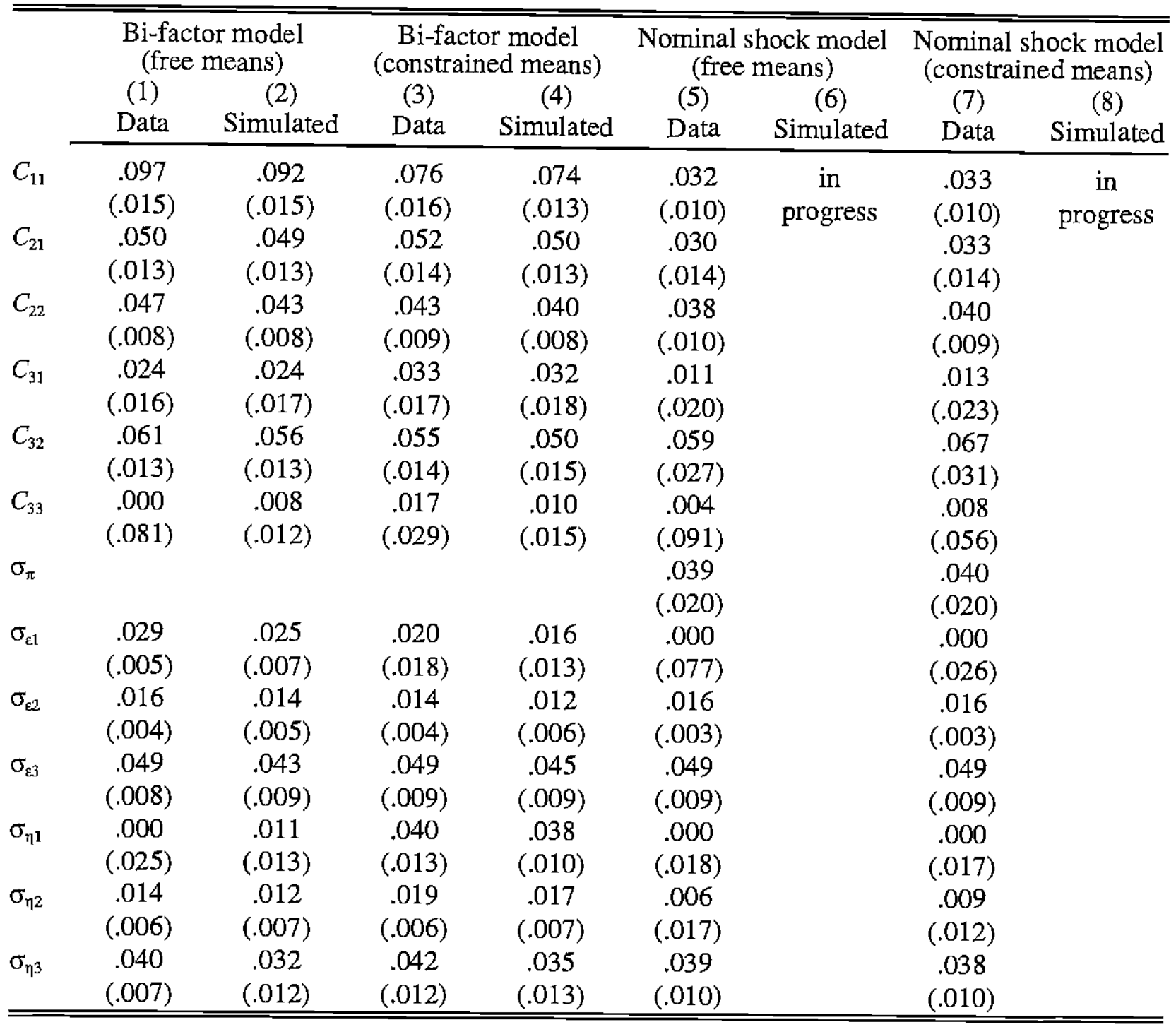




\section{Appendix B: Construction Deflators}

This appendix compares the alternative price index I develop for the construction industry with other measures of construction cost inflation. As noted above, since 1990 the CSY has a published an investment price index, and I use the construction component of that index to measure construction inflation in the period 1990-1998. I extend the index back to 1978 using CSY data on the unit cost (per sq. metre) of state capital construction (which excludes land cost, demolition and removal and investment in outdoor supplementary projects). In Table B-I below I compare the growth of the alternative price index with the official construction GDP deflator, based upon the implicit enterprise output deflators, and other measures of construction costs, which are available for various subperiods. ${ }^{72}$ While the alternative price index grows faster than the official deflator, it shows considerably less inflation than the other potential candidates. Since the other measures may be contaminated by increases in the cost of land, in developing my six-sector measures of GDP growth (in Section II), I opt for my alternative construction price index, which provides the most conservative alternative measure of construction costs. I should note that all measures, including the official GDP deflator, show a large rise in the relative price of construction, which underlies the rise in the relative price of capital discussed in Section V.

Table B-I: Measures of Construction Cost Inflation

\begin{tabular}{|c|c|c|c|c|c|}
\hline & $1978-98$ & $1981-98$ & $1983-98$ & $1987-98$ & $1994-98$ \\
\hline Alternative Deflator & 10.6 & 10.8 & 11.1 & 10.7 & 3.2 \\
\hline $\begin{array}{l}\text { Official Enterprise-based } \\
\text { GDP Output Deflator }\end{array}$ & 8.2 & & & & \\
\hline $\begin{array}{l}\text { Overall Construction Investment/ } \\
\text { Floor Space of Buildings Completed }\end{array}$ & & 15.1 & & & \\
\hline $\begin{array}{l}\text { Value of Buildings Completed/ Floor } \\
\text { Space (Urban Private Investment) }\end{array}$ & & & 12.5 & & \\
\hline $\begin{array}{l}\text { Cost of Buildings Completed } \\
\text { (Rural Private Investment) }\end{array}$ & & & 15.0 & & \\
\hline $\begin{array}{l}\text { Value of Commercial Building Sales/ } \\
\text { Floor Space of Buildings Sold }\end{array}$ & & & & 14.7 & \\
\hline $\begin{array}{l}\text { Cost of Buildings Completed } \\
\text { (Real Estate Development Data) }\end{array}$ & & & & & 10.6 \\
\hline
\end{tabular}

${ }^{72}$ All of the non-GDP data can be found in the section on Investment in Fixed Assets in the annual issues of the CSY, with the GDP deflator coming from the section on National Accounts. 
Table I: Gross Industrial Output and Value Added (100 million Yuan)

\begin{tabular}{rllllllrrr}
\hline \hline & \multicolumn{2}{c}{ Gross Output } & \multicolumn{3}{c}{ of which: } & \multicolumn{2}{c}{ National Accounts } \\
& & \multicolumn{2}{c}{ State enterprises } & Township \& village & \multicolumn{2}{c}{ Value Added } \\
\hline & Original & Revised & \multicolumn{2}{c}{ Original } & Revised & Original & Revised & Original & Revised \\
1990 & 23924 & 23924 & 13064 & 13064 & 4835 & & 6858.0 & 6858.0 \\
1991 & 28248 & 26625 & 14955 & 14955 & 5935 & & 8087.1 & 8087.1 \\
1992 & 37066 & 34599 & 17824 & 17824 & 8957 & 7166 & 10284.5 & 10284.5 \\
1993 & 52692 & 48402 & 22725 & 22725 & 13950 & 10537 & 14143.8 & 14143.8 \\
1994 & 76909 & 70176 & 26201 & 26201 & 23423 & 17760 & 18358.6 & 19359.6 \\
\hline \hline
\end{tabular}

Note: "Original", CSY 1995; "Revised", CSY 1996 and later.

Table II: Nominal GDP of the Service Sector (100 million Yuan)

\begin{tabular}{lrrr}
\hline \hline & 1994 CSY & 1995 CSY & 1999 CSY \\
\cline { 2 - 4 } 1978 & 824.8 & 860.5 & 860.5 \\
1980 & 918.6 & 966.4 & 966.4 \\
1984 & 1527.0 & 1769.8 & 1769.8 \\
1985 & 2119.2 & 2556.2 & 2556.2 \\
1986 & 2431.0 & 2945.6 & 2945.6 \\
1987 & 2851.2 & 3506.6 & 3506.6 \\
1988 & 3656.0 & 4510.1 & 4510.1 \\
1989 & 4491.6 & 5403.2 & 5403.2 \\
1990 & 4946.9 & 5796.3 & 5813.5 \\
1991 & 5797.5 & 7227.0 & 7227.0 \\
1992 & 6863.4 & 9135.9 & 9138.6 \\
1993 & 8485.4 & 11204.5 & 11323.8 \\
\hline \hline
\end{tabular}

Table III: Average Rates of Inflation (1978-1998)

\begin{tabular}{llc}
\hline \hline Primary & Implicit Deflator & 8.5 \\
Sector & Farm \& Sideline Products Purchasing Price Index & 7.9 \\
Secondary & Implicit Deflator & 4.4 \\
Sector & Ex-Factory Industrial Price Index & 6.1 \\
& Industrial Products Rural Retail Price Index & 5.3 \\
& Retail Price Index & 6.6 \\
Tertiary & Implicit Deflator & 7.1 \\
Sector & Consumer Price Index (Services) & 10.7 \\
\hline \hline
\end{tabular}


Table IV: Latent Variable Models

\begin{tabular}{|c|c|c|c|c|c|c|c|c|}
\hline & & & $\begin{array}{r}\text { Bi-fac } \\
\text { (constrai }\end{array}$ & $\begin{array}{l}r \text { model } \\
\text { ed means) }\end{array}$ & $\begin{array}{r}\text { Nominal } \\
\text { (free }\end{array}$ & & & \\
\hline & $\begin{array}{c}(1) \\
\text { Data }\end{array}$ & $\begin{array}{c}(2) \\
\text { Simulated }\end{array}$ & $\begin{array}{c}(3) \\
\text { Data } \\
\end{array}$ & $\begin{array}{c}(4) \\
\text { Simulated }\end{array}$ & $\begin{array}{c}(5) \\
\text { Data }\end{array}$ & $\begin{array}{c}(6) \\
\text { Simulated }\end{array}$ & $\begin{array}{c}\text { (7) } \\
\text { Data }\end{array}$ & $\begin{array}{c}(8) \\
\text { Simulated }\end{array}$ \\
\hline$B_{P}$ & $\begin{array}{c}.636 \\
(.068)\end{array}$ & $\begin{array}{c}.654 \\
(.083)\end{array}$ & $\begin{array}{l}.905 \\
(.096)\end{array}$ & $\begin{array}{c}.902 \\
(.087)\end{array}$ & $\begin{array}{c}1.32 \\
(.386)\end{array}$ & $\begin{array}{c}\text { in } \\
\text { progress }\end{array}$ & $\begin{array}{c}1.31 \\
(.391)\end{array}$ & $\begin{array}{l}\text { in } \\
\text { progress }\end{array}$ \\
\hline$B_{S}$ & $\begin{array}{c}.678 \\
(.065)\end{array}$ & $\begin{array}{c}.680 \\
(.074)\end{array}$ & $\begin{array}{c}.709 \\
(.049)\end{array}$ & $\begin{array}{c}.711 \\
(.052)\end{array}$ & $\begin{array}{c}.815 \\
(.137)\end{array}$ & & $\begin{array}{l}.756 \\
(.092)\end{array}$ & \\
\hline$B_{T}$ & $\begin{array}{c}.753 \\
(.202)\end{array}$ & $\begin{array}{c}.759 \\
(.247)\end{array}$ & $\begin{array}{l}.688 \\
(.103)\end{array}$ & $\begin{array}{c}.689 \\
(.106)\end{array}$ & $\begin{array}{c}.765 \\
(.312)\end{array}$ & & $\begin{array}{l}.630 \\
(.202)\end{array}$ & \\
\hline$\gamma_{P}$ & & & & & $\begin{array}{c}2.72 \\
(.611)\end{array}$ & & $\begin{array}{c}2.67 \\
(.592)\end{array}$ & \\
\hline$\gamma_{s}$ & & & & & $\begin{array}{c}1.35 \\
(.245)\end{array}$ & & $\begin{array}{c}1.25 \\
(.185)\end{array}$ & \\
\hline$\gamma_{T}$ & & & & & $\begin{array}{c}.913 \\
(.411)\end{array}$ & & $\begin{array}{l}.830 \\
(.397)\end{array}$ & \\
\hline $\bar{\pi}_{P}$ & $\begin{array}{c}.079 \\
(.022)\end{array}$ & $\begin{array}{l}.080 \\
(.023)\end{array}$ & $\begin{array}{c}.090 \\
(.019)\end{array}$ & $\begin{array}{c}.092 \\
(.020)\end{array}$ & & & $\begin{array}{c}.065 \\
(.022)\end{array}$ & \\
\hline $\bar{\pi}_{s}$ & $\begin{array}{c}.061 \\
(.016)\end{array}$ & $\begin{array}{c}.063 \\
(.017)\end{array}$ & $\begin{array}{c}.062 \\
(.015)\end{array}$ & $\begin{array}{c}.064 \\
(.017)\end{array}$ & & & $\begin{array}{l}.060 \\
(.016)\end{array}$ & \\
\hline $\bar{\pi}_{T}$ & $\begin{array}{l}.107 \\
(.017)\end{array}$ & $\begin{array}{l}.110 \\
(.018)\end{array}$ & $\begin{array}{l}.106 \\
(.017)\end{array}$ & $\begin{array}{l}.109 \\
(.018)\end{array}$ & & & $\begin{array}{l}.116 \\
(.036)\end{array}$ & \\
\hline $\ln L_{R}$ & 209.99 & 220.86 & 204.99 & 214.62 & 212.72 & & 212.35 & \\
\hline $\operatorname{lnL} L_{u}$ & 214.70 & 225.45 & 214.70 & 220.49 & 214.70 & & 214.70 & \\
\hline $5 \% \times$ & 6.30 & 9.47 & 8.46 & 11.44 & 3.00 & & 4.75 & \\
\hline$P$ & 21 & 21 & 18 & 18 & 25 & & 23 & \\
\hline
\end{tabular}

Notes: $\mathrm{LnL}_{\mathrm{R}}$ and $\ln \mathrm{L}_{\mathrm{U}}$ report the model and unrestricted $\ln$ likelihood, respectively. $5 \% \mathrm{X}$ $=5 \%$ critical value for difference between unrestricted and restricted ln likelihoods, according to chi squared and simulated distribution. "P" = parameters used in estimating the 21 covariance and 6 mean moments. 
Table V: Estimated Growth of Real GDP (1978-1998)

Official

Alternative

\begin{tabular}{cc} 
Aggregate & Non-Agricultural \\
\hline .091 & .106 \\
.074 & .081 \\
\hline
\end{tabular}

Table VI: Six-Sector Double-Deflated Growth Estimates

\begin{tabular}{lcc}
\hline \multicolumn{1}{c}{ Inflation by sector } & Official & Adjusted \\
Primary & .085 & .079 \\
Industry & .040 & .061 \\
Construction & .082 & .106 \\
Transport & .073 & \\
Wholesale \& retail trade & .070 & .066 \\
Other Services & .069 & .107 \\
$\quad$ Growth of real GDP & Aggregate & Non-Agricultural \\
Output deflators & .077 & .086 \\
Value added deflators & .072 & .080 \\
\hline \hline
\end{tabular}

Table VII: Chinese Population and Labour Force Data (millions)

\begin{tabular}{cccccc}
\hline \hline & \multicolumn{2}{c}{ China Statistical Yearbook } & \multicolumn{2}{c}{ Census Sources } \\
& Population & \multicolumn{2}{c}{ Employment } & Population & $\begin{array}{c}\text { Working } \\
\text { Population }\end{array}$ \\
\cline { 2 - 6 } & & Old Series & Revised & & \\
1978 & 963 & 402 & 402 & $\cdot$ & \\
1982 & 1017 & 453 & 453 & 1008 & 522 \\
$\cdot$ & $\cdot$ & $\cdot \cdot$ & $\cdot$ & $\cdot$ & $\cdot$ \\
1989 & 1127 & 553 & 553 & 1134 & 647 \\
1990 & 1143 & 567 & 639 & & \\
$\cdot$ & $\cdot$ & $\cdot$ & 6 & & \\
1997 & 1236 & 637 & 696 & & \\
1998 & 1248 & 624 & 700 & & 2.7 \\
Growth: & & & & & \\
$82-90$ & 1.5 & 2.8 & 4.3 & 1.5 & \\
$78-98$ & 1.3 & 2.2 & 2.8 & & \\
\hline \hline
\end{tabular}

Notes: Total population numbers include the military, while the working population figures do not. "Old series" employment data for 1997-1998 based upon author's calculations. 
Table VIII: Participation Rates by Age and Sex

\begin{tabular}{lllllll}
\hline \hline & \multicolumn{2}{c}{1982 Census } & \multicolumn{2}{c}{1990 Census } & \multicolumn{2}{c}{ 1997 Survey } \\
& $\mathrm{M}$ & $\mathrm{F}$ & $\mathrm{M}$ & $\mathrm{F}$ & $\mathrm{M}$ & $\mathrm{F}$ \\
\cline { 2 - 7 } Overall & .57 & .47 & .61 & .53 & .62 & .56 \\
$15-19$ & .71 & .78 & .62 & .68 & .44 & .47 \\
$20-24$ & .96 & .90 & .93 & .90 & .92 & .89 \\
$25-29$ & .99 & .89 & .98 & .91 & .97 & .91 \\
$30-34$ & .99 & .89 & .99 & .91 & .98 & .92 \\
$35-39$ & .99 & .88 & .99 & .91 & .98 & .92 \\
$40-44$ & .99 & .83 & .99 & .88 & .98 & .91 \\
$45-49$ & .97 & .71 & .98 & .81 & .97 & .85 \\
$50-54$ & .91 & .51 & .93 & .62 & .93 & .72 \\
$55-59$ & .83 & .33 & .84 & .45 & .82 & .53 \\
$60-64$ & .64 & .17 & .63 & .27 & .62 & .37 \\
$\geq 65$ & .30 & .05 & .33 & .08 & .34 & .16 \\
\hline \hline
\end{tabular}

Note: 1982 and 1990 Census exclude military personnel from the numerator and denominator. 1997 data do not specify.

Table IX: Demographic Trends

\begin{tabular}{ccccccccccc}
\hline \hline & \multicolumn{4}{c}{ Distribution by Age Group } & \multicolumn{4}{c}{ Surviving/Original Members } \\
& 1982 & Census & \multicolumn{1}{c}{ 1990 Census } & \multicolumn{1}{c}{ 1997 } & Survey & \multicolumn{2}{c}{$1990 / 1982$} & \multicolumn{1}{c}{$1997 / 1990$} \\
& $\mathrm{M}$ & $\mathrm{F}$ & $\mathrm{M}$ & $\mathrm{F}$ & $\mathrm{M}$ & $\mathrm{F}$ & $\mathrm{M}$ & $\mathrm{F}$ & $\mathrm{M}$ & $\mathrm{F}$ \\
\cline { 2 - 11 } $0-4$ & .10 & .09 & .10 & .10 & .07 & .06 & 1.03 & 1.03 & 1.09 & 1.10 \\
$5-9$ & .11 & .11 & .09 & .09 & .10 & .09 & 0.99 & 0.99 & 1.02 & 1.01 \\
$10-14$ & .13 & .13 & .09 & .09 & .09 & .09 & 0.97 & 0.98 & 0.84 & 0.85 \\
$15-19$ & .12 & .13 & .11 & .11 & .08 & .07 & 1.01 & 0.99 & 0.89 & 0.95 \\
$20-24$ & .07 & .07 & .11 & .11 & .08 & .08 & 1.03 & 0.99 & 0.98 & 1.02 \\
$25-29$ & .09 & .09 & .09 & .09 & .10 & .11 & 0.98 & 0.98 & 1.02 & 1.05 \\
$30-34$ & .07 & .07 & .08 & .07 & .10 & .10 & 0.99 & 0.99 & 0.99 & 1.03 \\
$35-39$ & .06 & .05 & .08 & .08 & .06 & .06 & 0.97 & 0.98 & 1.01 & 1.05 \\
$40-44$ & .05 & .05 & .06 & .06 & .08 & .08 & 0.96 & 0.97 & 1.03 & 1.08 \\
$45-49$ & .05 & .05 & .04 & .04 & .06 & .06 & 0.93 & 0.95 & 1.00 & 1.08 \\
$50-54$ & .04 & .04 & .04 & .04 & .05 & .05 & 0.90 & 0.93 & 0.99 & 1.08 \\
$55-59$ & .03 & .03 & .04 & .04 & .04 & .04 & 0.83 & 0.88 & 0.95 & 1.03 \\
$60-64$ & .03 & .03 & .03 & .03 & .04 & .04 & 0.74 & 0.81 & 0.89 & 0.95 \\
$\geq 65$ & .04 & .06 & .05 & .06 & .07 & .08 & 0.47 & 0.54 & 0.61 & 0.67 \\
\hline \hline
\end{tabular}


Table X: Distribution of the Working Population by Economic Sector

\begin{tabular}{ccccc}
\hline & \multicolumn{2}{c}{ Labour Force of Society } & \multicolumn{2}{c}{ Population Census } \\
& Agricultural & Non-agricultural & Agricultural & Non-agricultural \\
\cline { 2 - 5 } 1978 & .71 & .29 & & .27 \\
1982 & .68 & .32 & .73 & .28 \\
1990 & .60 & .40 & & \\
1998 & .53 & .47 & & 3.3 \\
absolute growth & & & & \\
$82-90$ & 1.3 & 5.6 & & \\
$78-98$ & 0.8 & 4.5 & & \\
\hline \hline
\end{tabular}

Table XI: Industrial ${ }^{*}$ Employment (millions)

\begin{tabular}{|c|c|c|c|}
\hline & Labour Force of Society & Population Census & Industrial Census \\
\hline $\begin{array}{c}1982 \\
1985 \\
1990 \\
1995 \\
\text { absolute }\end{array}$ & rowth & $\begin{array}{l}72 \\
87\end{array}$ & 147 \\
\hline $\begin{array}{l}82-90 \\
85-95\end{array}$ & $\begin{array}{l}3.7 \\
2.8\end{array}$ & 2.4 & 4.5 \\
\hline
\end{tabular}
tion.

(*) Mining, manufacturing \& utilities, i.e. the secondary sector other than construc-

Table XII: Consistency between National

Income, Wage \& Employment Data (non-agricultural growth rates, 1978-1998)

\begin{tabular}{lr}
\hline \hline Nominal GDP & 16.1 \\
Weighted wages & 12.5 \\
Share of labour & 1.4 \\
Implied employment growth & 5.0 \\
& \\
Reported employment growth & 4.5 \\
\hline \hline
\end{tabular}


Table XIII: Distribution of the Working Population by Sex, Education and Age Characteristics

\begin{tabular}{|c|c|c|c|c|c|c|c|c|c|c|c|}
\hline & & & Sex & & & & & & ge Grc & & \\
\hline & 1982 & 1987 & 1990 & 1995 & 1997 & & 1982 & 1987 & & 1995 & 1997 \\
\hline M & & .555 & .550 & .543 & .535 & $<20$ & .178 & .140 & .120 & .070 & .057 \\
\hline $\mathrm{F}$ & .437 & .445 & & & .465 & $20-2$ & .133 & .191 & .177 & .138 & .120 \\
\hline & & & & & & 25 & .167 & .119 & .152 & . 168 & .167 \\
\hline & & iducati & nal At & ainme & & $30-34$ & .132 & . 144 & .123 & . 147 & .164 \\
\hline & $\frac{1982}{282}$ & 1987 & $\underline{1990}$ & $\underline{1995}$ & 199 & & .098 & .114 & .127 & .116 & .103 \\
\hline & .282 & .229 & .169 & .126 & .116 & $40-44$ & .085 & .083 & .092 & .123 & .124 \\
\hline & .344 & .363 & .378 & .372 & .32 & 45 & .077 & .069 & & .088 & .095 \\
\hline & .366 & .396 & .434 & .473 & .50 & & .057 & .059 & .055 & .060 & .065 \\
\hline Tertiary & .009 & .012 & .019 & .029 & .035 & & .038 & .041 & .04 & .044 & .045 \\
\hline & & & & & & & .02 & .023 & .024 & .027 & .031 \\
\hline & & & & & & & .015 & .017 & .019 & .020 & .029 \\
\hline
\end{tabular}

Table XIV: Rise in the Educational Attainment of 1982 Census Cohorts

\begin{tabular}{|c|c|c|c|c|c|c|c|c|c|c|c|c|}
\hline & \multicolumn{4}{|c|}{1982 Distribution by Age } & \multicolumn{4}{|c|}{ Shift in Distribution $1982-90$} & \multicolumn{4}{|c|}{ Increase (millions) $1982-90$} \\
\hline & $\mathrm{N}$ & $\mathrm{P}$ & $S$ & $\mathrm{~T}$ & $\mathrm{~N}$ & $\mathrm{P}$ & $\mathrm{S}$ & $\mathrm{T}$ & $\mathrm{N}$ & $\mathrm{P}$ & & $\mathrm{T}$ \\
\hline $15-19$ & .094 & .282 & .619 & .005 & -.029 & -.000 & .004 & .025 & -3.67 & -0.18 & 0.18 & 3.15 \\
\hline 2 & .14 & .23 & .61 & .06 & & .044 & & & & 3.51 & -0.49 & 1.06 \\
\hline 2 & & .33 & .43 & .00 & 0 & .054 & .0 & & & 4. & & \\
\hline $30-3$ & .262 & .443 & .287 & .00 & & .041 & .0 & & & & 1.08 & 0.7 \\
\hline & .280 & .431 & .275 & .014 & 6 & .024 & .01 & .00 & -2 . & 0. & & 0. \\
\hline 4( & .38 & .385 & .206 & .022 & -.039 & .02 & .0 & & & & 0.15 & 0. \\
\hline $45-4$ & .52 & .331 & .131 & .01 & & .02 & .0 & .00 & -3.27 & 0.16 & -0.01 & 0. \\
\hline & $.61^{\prime}$ & .272 & .101 & .005 & -.027 & .021 & .00 & .00 & & -0.19 & & \\
\hline & & .187 & .05 & .00 & -.026 & .019 & .006 & .002 & -28.76 & -5.18 & -1.36 & -0.02 \\
\hline
\end{tabular}

Note: N, P, S \& T denote "none", "primary", "secondary" and "tertiary", respectively. 
Table XV: Proportion of Individuals Reporting Tertiary and Secondary Education Attained through Adult Education (1995 Survey)

\begin{tabular}{lcccc}
\hline \hline & \multicolumn{2}{c}{ Tertiary } & \multicolumn{2}{c}{ Upper Secondary } \\
& Male & Female & Male & Female \\
\cline { 2 - 5 } $15-19$ & .22 & .23 & .04 & .05 \\
$20-24$ & .29 & .35 & .07 & .08 \\
$25-29$ & .36 & .40 & .08 & .08 \\
$30-34$ & .47 & .52 & .07 & .07 \\
$35-39$ & .58 & .59 & .07 & .08 \\
$40-44$ & .59 & .55 & .12 & .14 \\
$45-49$ & .52 & .46 & .14 & .12 \\
$50-54$ & .32 & .23 & .12 & .08 \\
$55-59$ & .22 & .14 & .11 & .07 \\
$60-64$ & .22 & .14 & .11 & .08 \\
$\geq 65$ & .17 & .09 & .09 & .06 \\
\hline \hline
\end{tabular}

Table XVI: Mainstream and Adult Education (1998)

\begin{tabular}{lrcrrrr}
\hline \hline & \multicolumn{3}{c}{ Mainstream } & & Adult & \\
& Students & Graduates & Full-time & & & \\
& Teachers & Students & Graduates & Teachers \\
\cline { 2 - 7 } Primary & 139538 & 21174 & 5819 & 5386 & 5485 & 64 \\
Secondary & 73407 & 21241 & 4312 & 66760 & 88530 & 342 \\
$\quad$ peasant technical training & & & & 59830 & 82019 & 140 \\
Tertiary & 3409 & 830 & 407 & 2822 & 826 & 97 \\
\hline \hline
\end{tabular}

Note: 1000s of persons. S: CSY 1999, Tables 20-1 \& 20-21. 
Table XVII: Consistency between 1990 Census and 1995 Sample Survey

\begin{tabular}{|c|c|c|c|c|c|c|c|}
\hline & \multicolumn{2}{|c|}{$\begin{array}{c}\text { Growth of } 1990 \\
\text { cohort size }\end{array}$} & & \multicolumn{4}{|c|}{$\begin{array}{l}\text { Shift in educational } \\
\text { distribution by age cohort }\end{array}$} \\
\hline & $\mathbf{M}$ & $\mathrm{F}$ & & $\mathrm{N}$ & $\mathrm{P}$ & $S$ & $\mathrm{~T}$ \\
\hline $\begin{array}{c}0-4 \\
5-9 \\
10-14 \\
15-19 \\
20-24 \\
25-29 \\
30-34 \\
35-39 \\
40-44 \\
45-49 \\
50-54 \\
55-59 \\
60-64 \\
\geq 65\end{array}$ & $\begin{array}{l}1.13 \\
1.09 \\
0.94 \\
0.86 \\
0.95 \\
1.01 \\
1.00 \\
1.04 \\
1.05 \\
1.04 \\
1.02 \\
1.00 \\
0.96 \\
0.75\end{array}$ & $\begin{array}{l}1.13 \\
1.09 \\
0.94 \\
0.93 \\
1.03 \\
1.07 \\
1.05 \\
1.08 \\
1.10 \\
1.10 \\
1.07 \\
1.06 \\
1.03 \\
0.80\end{array}$ & $\begin{array}{c}15-19 \\
20-24 \\
25-29 \\
30-34 \\
35-39 \\
40-44 \\
45-49 \\
50-54 \\
55-59 \\
\geq 60\end{array}$ & $\begin{array}{l}-.010 \\
-.012 \\
-.014 \\
-.019 \\
-.022 \\
-.017 \\
-.013 \\
-.015 \\
-.007 \\
-.022\end{array}$ & $\begin{array}{r}-.046 \\
-.001 \\
.018 \\
.012 \\
.014 \\
.017 \\
.015 \\
.012 \\
.008 \\
.016\end{array}$ & $\begin{array}{r}.025 \\
.006 \\
-.012 \\
-.002 \\
.000 \\
-.006 \\
-.007 \\
-.003 \\
-.006 \\
.003\end{array}$ & $\begin{array}{l}.031 \\
.007 \\
.008 \\
.009 \\
.007 \\
.006 \\
.005 \\
.006 \\
.005 \\
.003\end{array}$ \\
\hline
\end{tabular}

Note: Growth of cohort size includes military personnel in both population estimates. Shift in educational distribution does not include military personnel in 1990 figures. N, P, S \& T denote "none", "primary", "secondary" and "tertiary", respectively. 
Table XVIII: Measures of Worker Characteristics

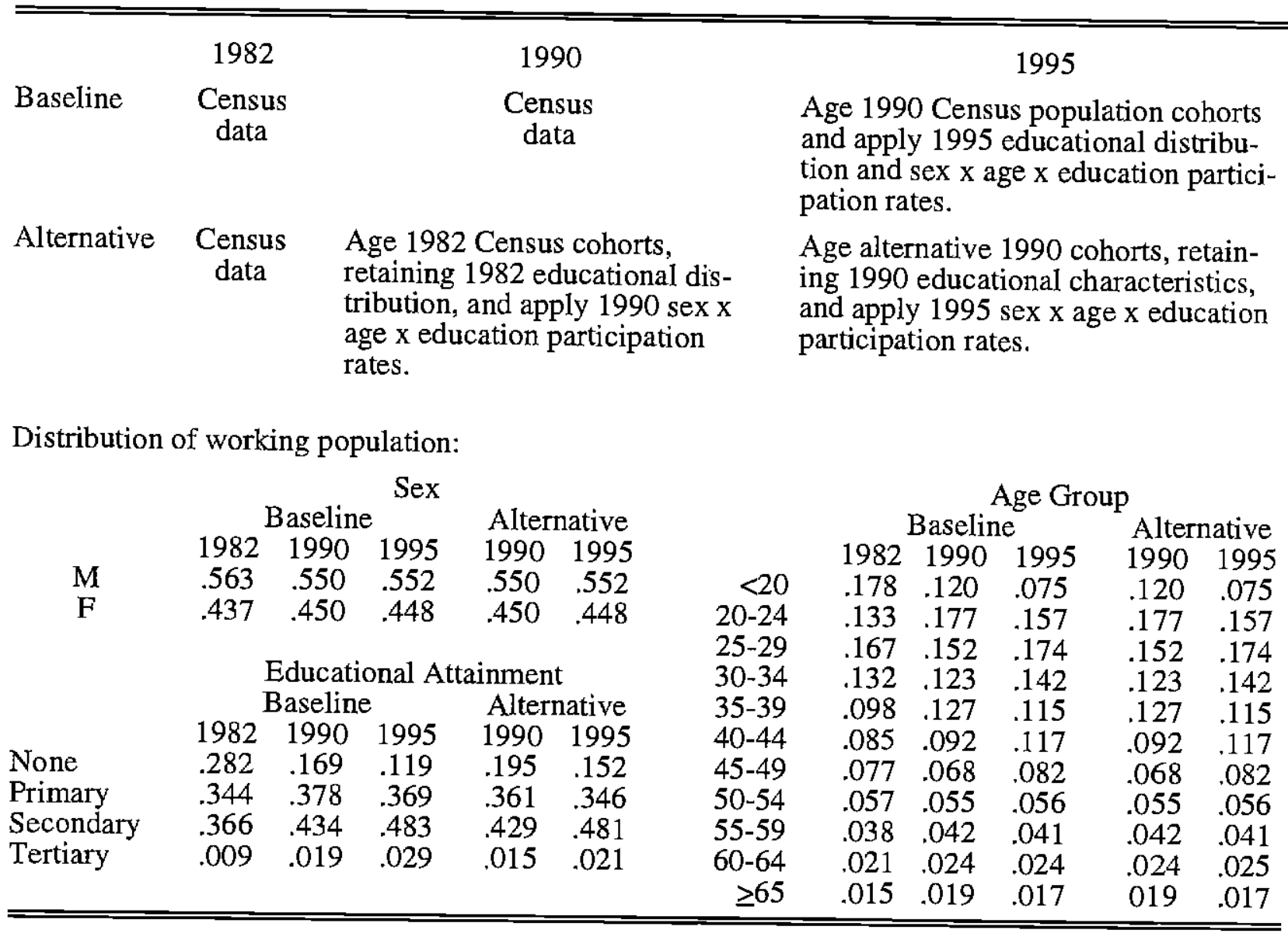


Table XIX: Ln Wage Profiles by Employee Characteristics (relative to base group)

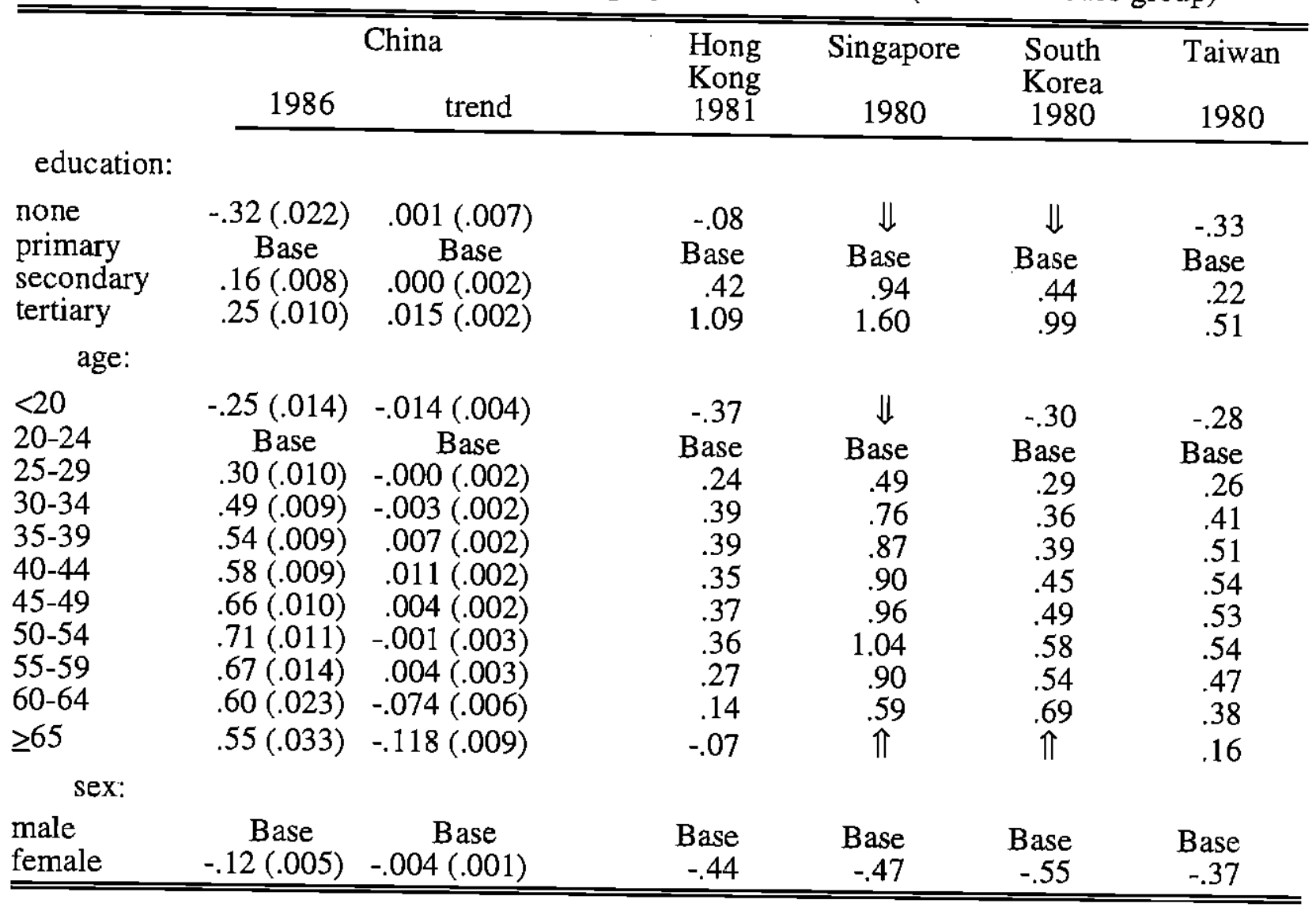

Note: $\Uparrow$ or $\Downarrow$ signify "included in adjacent group". Standard errors in parentheses.

Table XX: Growth of Human Capital (1978-98)

\begin{tabular}{lcccccc}
\hline \hline & & \multicolumn{5}{c}{ Income Weights } \\
& China & HK & SI & SK & TW & Avg. NIC \\
Original & .011 & .011 & .019 & .010 & .011 & .013 \\
Baseline & .011 & .011 & .018 & .010 & .011 & .013 \\
Alternative & .010 & .010 & .016 & .009 & .010 & .011 \\
Non-agricultural & .008 & .012 & .017 & .010 & .008 & .012 \\
\hline \hline
\end{tabular}


Table XXI: Growth of Official and Alternative Deflators

\begin{tabular}{lccc}
\hline \hline & Official & \multicolumn{2}{c}{ Alternative } \\
& $1978-95$ & $1978-95$ & $1978-98$ \\
GDP (Production) & 7.1 & 8.9 & 8.1 \\
Farm Consumption & 7.1 & 7.8 & 7.1 \\
Non-farm Consumption & 8.4 & 8.6 & 7.8 \\
Government Consumption & 5.6 & 9.4 & 9.2 \\
Inventories & 7.9 & 7.8 & 6.5 \\
Exports & $\mathrm{NA}$ & 11.3 & 9.5 \\
Imports & $\mathrm{NA}$ & 11.0 & 8.8 \\
GFCF & 7.0 & 10.1 & 8.8 \\
\hline \hline
\end{tabular}

Table XXII: Non-Agricultural Growth Rates (1978-98)

\begin{tabular}{lcc}
\hline \hline & Capital & Capital/Output \\
Official Data & 9.2 & -1.4 \\
Alternative & 7.7 & -0.4 \\
\hline \hline
\end{tabular}


Table XXIII: Share of Labour in GDP at Factor Cost

\begin{tabular}{ccccc}
\hline \hline & \multicolumn{2}{l}{ National Accounts } & \multicolumn{2}{c}{ Input-Output Tables } \\
& GDP & Non-Agri. & GDP & Non-Agri. \\
1978 & .57 & .42 & & \\
1979 & .59 & .42 & & \\
1980 & .58 & .43 & & \\
1981 & .60 & .43 & & \\
1982 & .61 & .44 & & \\
1983 & .61 & .43 & & \\
1984 & .61 & .44 & & \\
1985 & .60 & .45 & & \\
1986 & .60 & .46 & .60 & .49 \\
1987 & .59 & .46 & .60 & \\
1988 & .59 & .47 & & \\
1989 & .59 & .47 & .63 & .52 \\
1990 & .61 & .49 & .63 & .40 \\
1991 & .60 & .49 & .52 & \\
1992 & .58 & .48 & & \\
1993 & .59 & .50 & & \\
1994 & .59 & .51 & .54 & .44 \\
1995 & .61 & .53 & & .56 \\
1996 & & & .63 & .56 \\
1997 & .60 & .46 & .58 & \\
Average & .60 &
\end{tabular}

Note: I-O data for 1987 and 1990 calculated from GDP at market prices and include under labour remuneration a residual category, "other", consisting of some payments to labour and elements of enterprise material consumption. 
Table XXIV: Non-Agricultural Labour Shares in the NICs (as estimated in Young 1995)

\begin{tabular}{|c|c|c|c|c|c|c|c|c|}
\hline & \multicolumn{4}{|c|}{ Adjusted } & \multicolumn{4}{|c|}{ Unadjusted } \\
\hline & HK & SI & SK & TW & HK & SI & SK & TW \\
\hline $\begin{array}{l}1961 \\
1966\end{array}$ & .62 & & & .74 & .50 & & & 55 \\
\hline $\begin{array}{l}1970 \\
1975\end{array}$ & $\begin{array}{l}.66 \\
.67\end{array}$ & .50 & $\begin{array}{l}.69 \\
.63\end{array}$ & .74 & $\begin{array}{l}.56 \\
.55\end{array}$ & .39 & $\begin{array}{l}.47 \\
.45\end{array}$ & .53 \\
\hline 1980 & .57 & .53 & .76 & .74 & .49 & .44 & .50 & .55 \\
\hline 1985 & .62 & & .70 & & .53 & & .49 & \\
\hline 1990 & .60 & 48 & .78 & .76 & .52 & .43 & .56 & .59 \\
\hline Average & .62 & .50 & .71 & .75 & .53 & .42 & .49 & .56 \\
\hline
\end{tabular}

Note: Hong Kong data for 1970 on refer to the year plus one, e.g. 1971 instead of 1970. Hong Kong and Singapore data refer to the entire economy, but the agricultural sectors are negligible.

Table XXV: Non-Agricultural Labour Shares by Sector in Korea and Taiwan (adjusted for unpaid workers, as estimated by Young 1995)

\begin{tabular}{cccccc}
\hline \hline & $\begin{array}{c}\text { Wholesale \& } \\
\text { retail trade }\end{array}$ & $\begin{array}{c}\text { Community, } \\
\text { social \& personal } \\
\text { services }\end{array}$ & & $\begin{array}{c}\text { Wholesale \& } \\
\text { retail trade }\end{array}$ & $\begin{array}{c}\text { Community, } \\
\text { social \& personal } \\
\text { services }\end{array}$ \\
${$\cline { 2 - 3 }$} }$ & & Taiwan \\
1970 & 1.20 & 0.98 & 1966 & 1.50 & \\
1975 & 1.01 & 0.96 & 1970 & 1.92 & 0.98 \\
1980 & 0.95 & 1.04 & 1980 & 1.18 & 1.06 \\
1985 & 0.86 & 1.04 & 1990 & 1.09 & 1.02 \\
1990 & 0.68 & 1.07 & & & \\
\hline \hline
\end{tabular}


Table XXVI: Gold into Base Metals

(Chinese growth rates, 1978-98)

\begin{tabular}{lcc}
\hline \hline \multicolumn{1}{c}{ Aggregate } & Official & Adjusted \\
Output per Capita & 7.8 & 6.1 \\
Output per Worker & 6.9 & 5.2 \\
$\quad$ & \\
$\quad$ Non-Agricultural & 6.1 & 3.6 \\
Output per Worker & 5.0 & 2.6 \\
Output per Effective Worker & 1.4 & 0.4 \\
Output per Unit of Capital & 3.0 & 1.4 \\
Total Factor Productivity & \\
\hline \hline
\end{tabular}




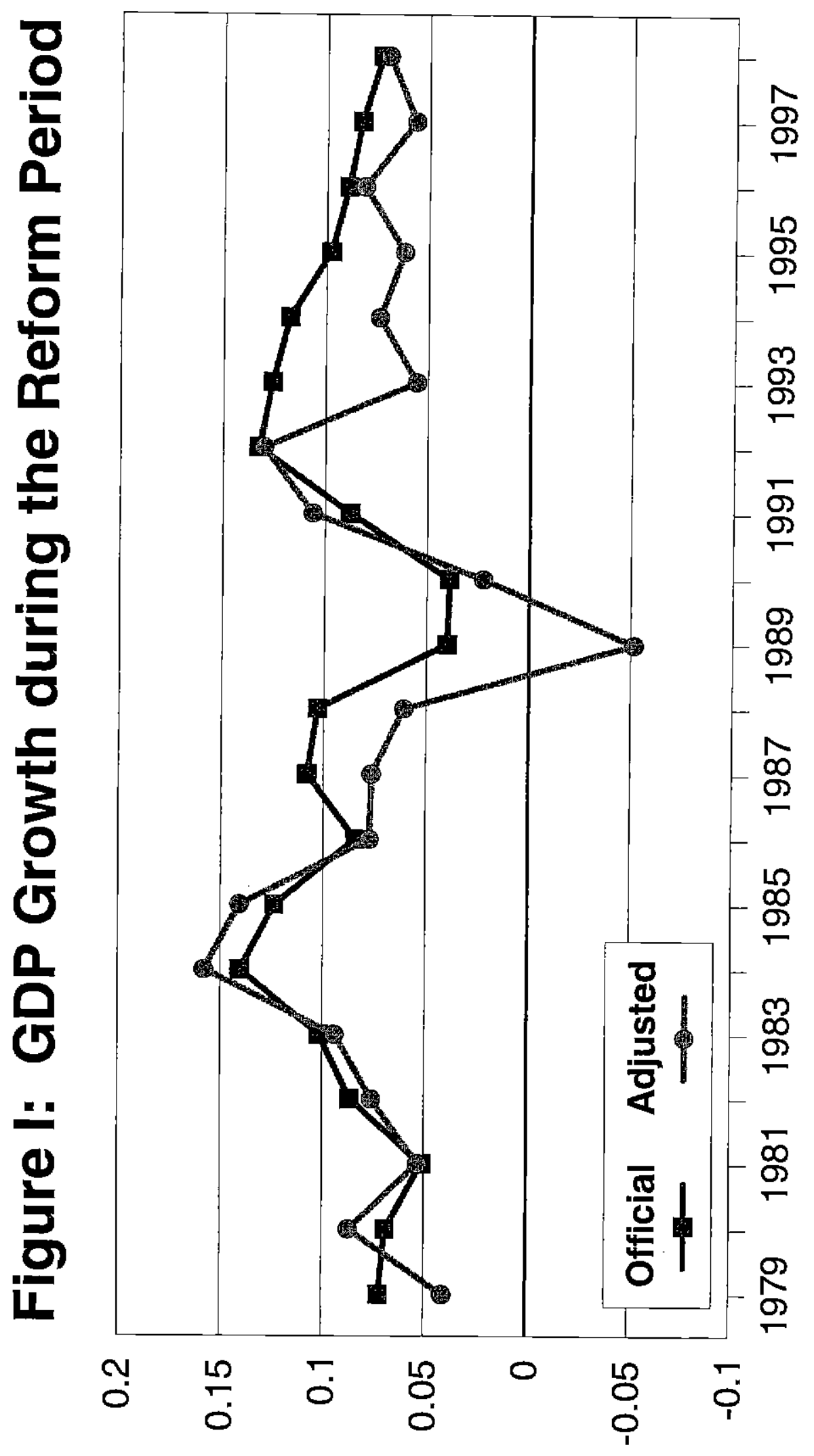




\section{Figure II: Investment over GDP}

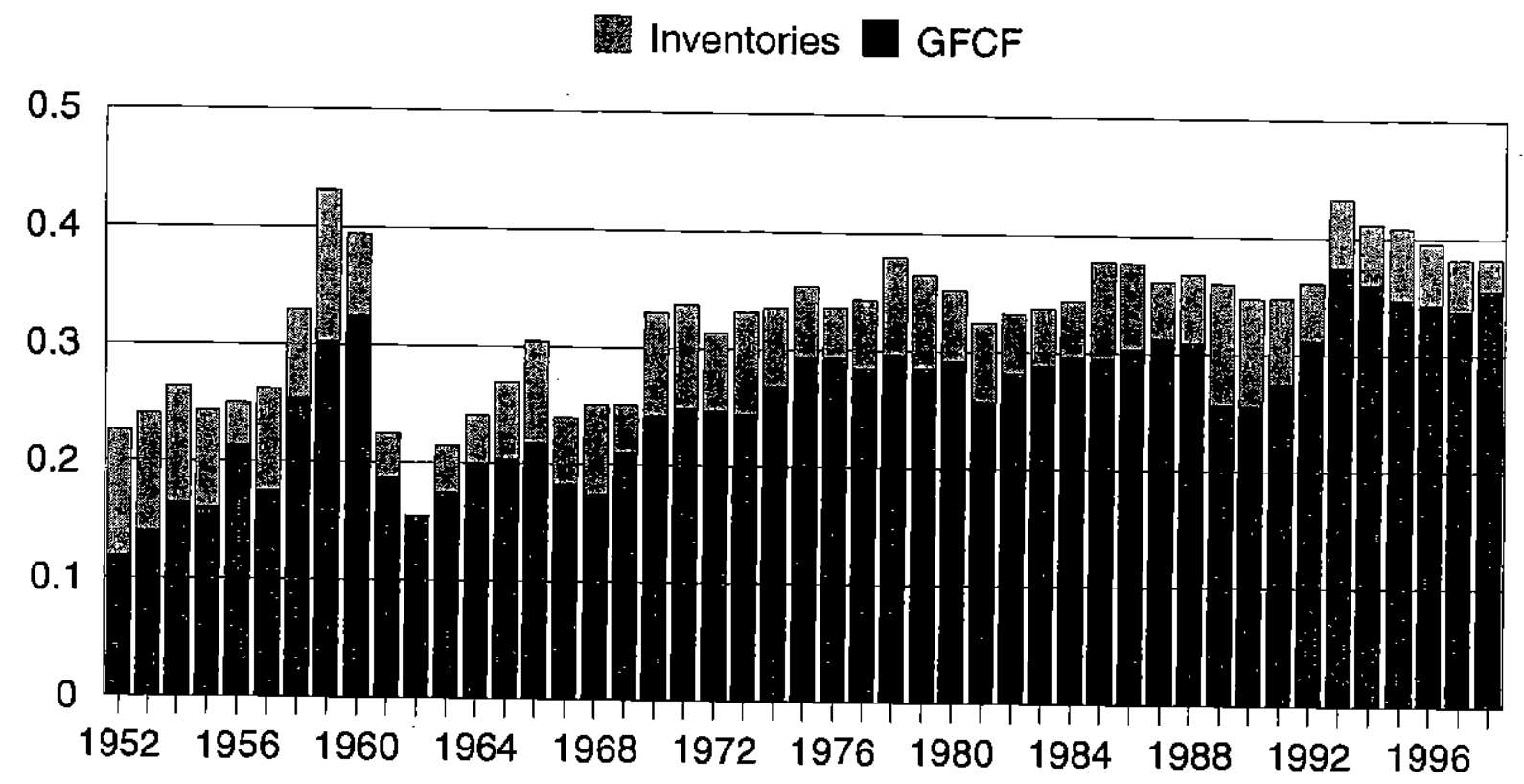

Figure III: Agricultural Share of Investment

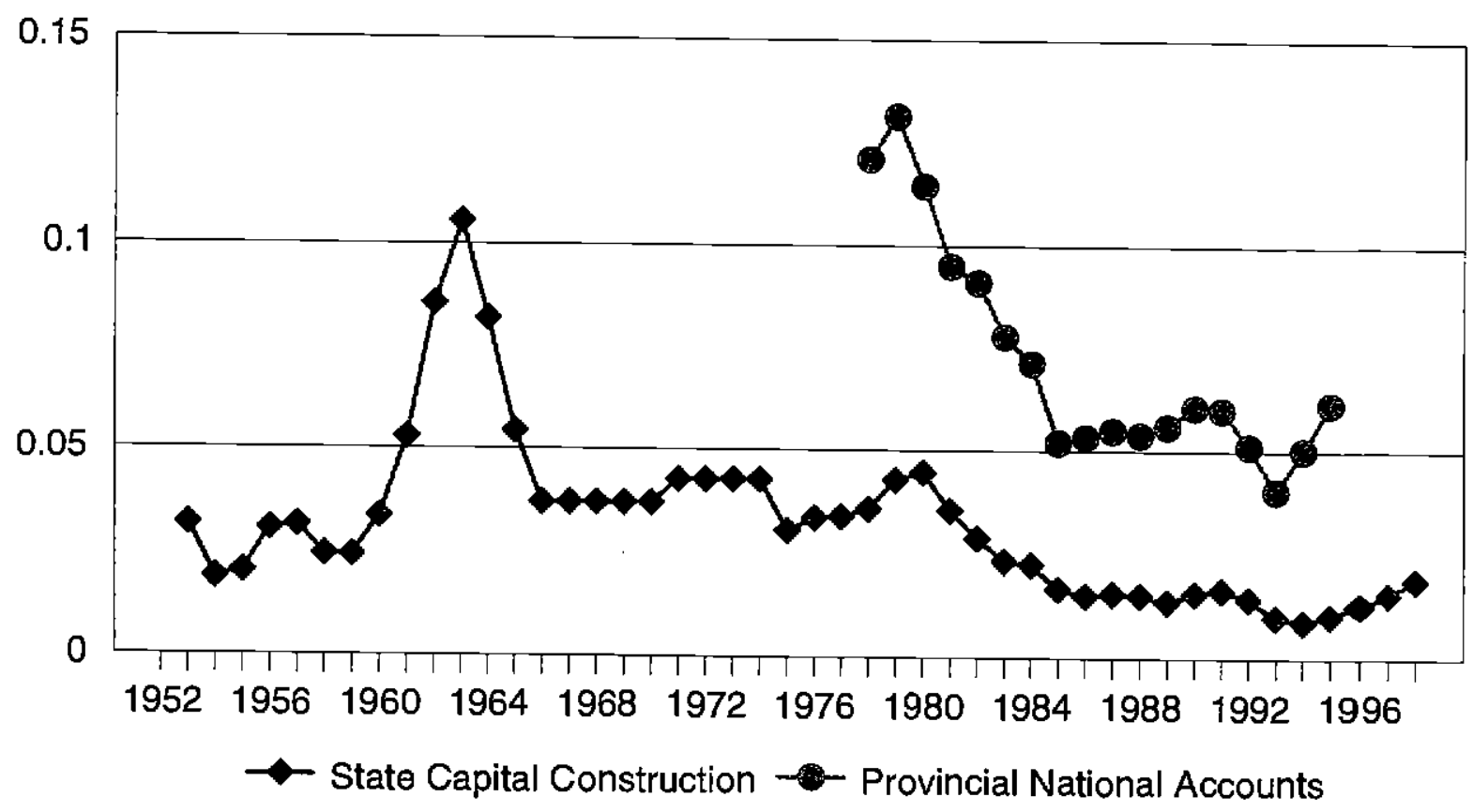


Figure IV: Official and Alternative GFCF Deflators $(1978=1.00)$

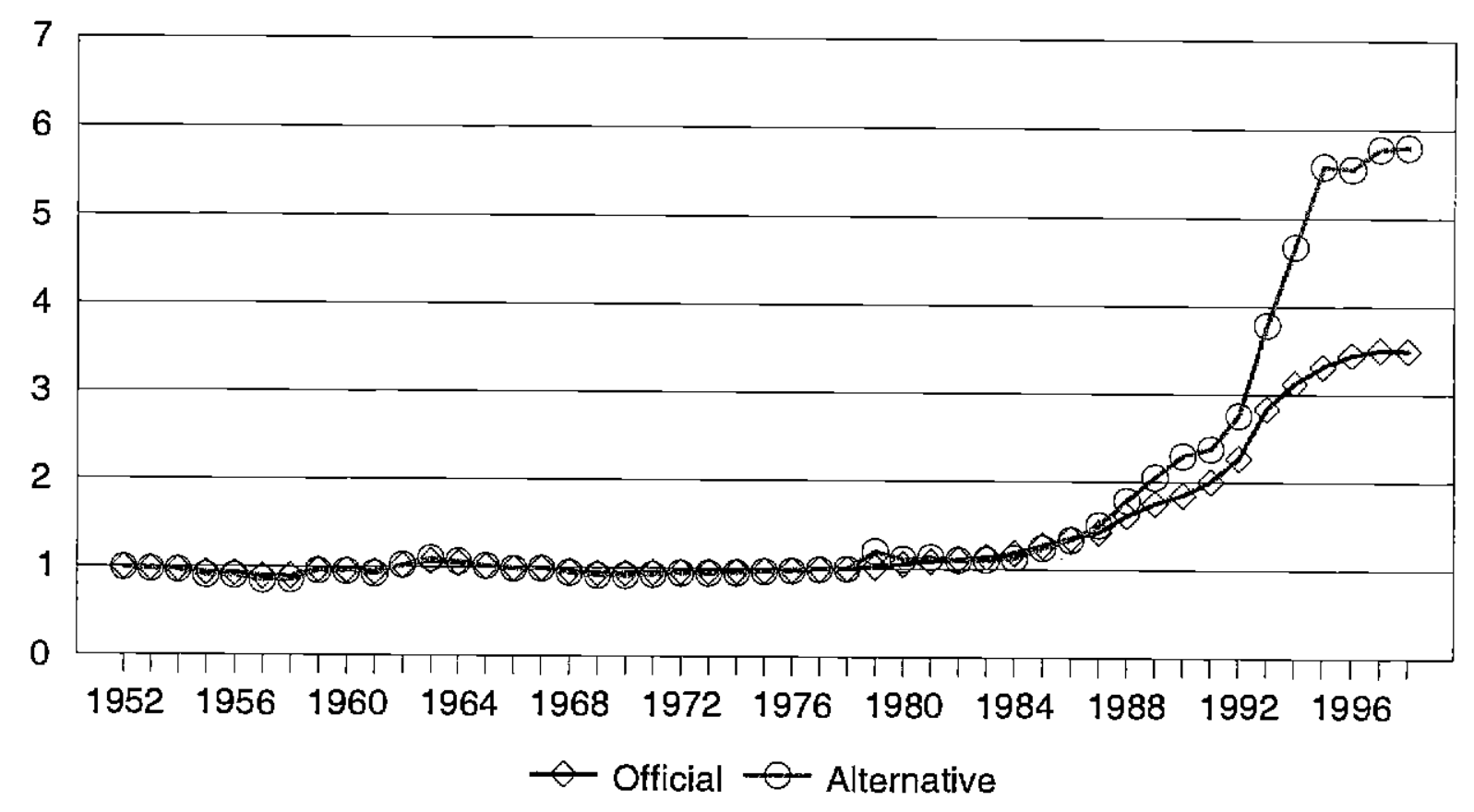

